\title{
Kosova’ya Yapılan Çerkes Göçü ve İskânı (1864-1865)*
}

\author{
Vahit Cemil Urhan** \\ Öz
}

XVI. yüzyıldan itibaren Kafkasya’yı hâkimiyeti altına almaya yönelik bir politika izlemeye başlayan ve 1864 yllında Kuzey Kafkasya'yı işgal eden Rusya, bölgede yaşayan Çerkesleri Osmanlı Devleti topraklarına göç etmeye zorlamıştır. 1850'lerde başlayan Çerkes göçleri 1862-1865 yılları arasında yoğunlaşmış ve 1860'ların sonuna kadar devam etmiştir. Sürekli isyanların yaşandığı Balkanlar'da Çerkeslerin savaşçllı̆̆ından yararlanmak ve Müslüman nüfusunu arttırmak isteyen Osmanlı Devleti, bu dönemde 400.000'den fazla Çerkes'i Rumeli'ye yerleştirmiştir. 9.000-11.000 civarında Çerkes de Kosova'ya iskân edilmiştir. Kosova'ya gelen Çerkesler burada köyler kurmuşlardır. Yeni vatanlarında tarım ve hayvancılıkla uğraşmaya başlamışlardır. Ancak, Kosova'ya yerleştirilen Çerkeslerin büyük bir kısmı burada kalıcı olmamıştır. Avrupa devletlerinin 23 Aralık 1876'da toplanan İstanbul Konferansı'nda Çerkeslerin Balkanlar'ı terk etmesini istemesi ve 1877-1878 Osmanlı-Rus Savaşı, Kosova'da yaşayan Çerkeslerin bir kısmının Anadolu'ya ve Ortadoğu'ya göç etmesine sebep olmuştur. Kosova'da geriye kalan Çerkeslerin büyük çoğunluğu da Balkan Savaşları sırasında ve sonrasında bölgeden ayrılmıştır.

Bu çalı̧̧mada, 1864-1865 yıllarında Kosova'ya yapılan Çerkes göçü ve iskânını hazırlayan gelişmeler, göç ve iskân sırasında karşlaşılan sorunlar ve bu sorunların çözümü için izlenen politikalar ele alınmıştır.

Anahtar Kelimeler: Göç, Çerkes, Kosova, Balkanlar, Rumeli, Osmanlı Devleti

* Bu makale, 18-21 Eylül 2019 tarihleri arasında Edirne'de düzenlenen "VII. Uluslararası Balkan Tarihi Araştırmaları Sempozyumu"nda "Kosova'ya Yapılan Çerkes Göçü ve İskânı (1864)" başlığıyla sunulmuş olan sözlü bildirinin genişletilmiş ve geliştirilmiş hâlidir.

** Dr. Öğr. Üyesi, Trakya Üniversitesi, Balkan Araştırma Enstitüsü, Edirne/TÜRKIYY, vahit.urhan@hotmail.com ORCID: 0000-0002-4301-0300

DOI: $10.37879 /$ belleten.2021.991

Makale Gönderim Tarihi: 12.11.2020 - Makale Kabul Tarihi: 05.04.2021

Belleten, Aralık 2021, Cilt: 85/Sayı: 304; 991-1024 


\title{
The Circassian Migration and Settlement in Kosovo (1864-1865)
}

\begin{abstract}
From the $\mathrm{XVI}^{\text {th }}$ century onwards, Russia, which began that began to pursue a policy to dominate the Caucasus and occupied North Caucasus in 1864, forced Circassians to migrate to the territory of the Ottoman Empire. Circassian immigration that began in the 1850's, intensified between 1862 and 1865 and continued until the end of the 1860's. During this period, as continuous rebellions took place in the Balkans, the Ottoman Empire who wanted to benefit from the militancy of Circassians and increase the Muslim population, settled more than 400.000 Circassians in Rumelia. Approximately 9.000-11.000 Circassians were also settled in Kosovo. The Circassians who came to Kosovo established villages. They began to deal with agriculture and husbandry in their new homeland. However, the majority of Circassians who settled in Kosovo could not remain therein. European states wanted Circassians to leave the Balkans at the Istanbul Conference held on December 23, 1876, and the OttomanRussian War of 1877-1878 caused some of the Circassians living in Kosovo to migrate to Anatolia and the Middle East. The majority of the remaining Kosovo Circassians also left Kosovo during and after the Balkan Wars.

In this study, the process that prepared Circassian immigration and settlement to Kosovo between 1864-1865, the problems encountered during immigration and settlement and the policies followed for the solution of these problems are discussed.
\end{abstract}

Keywords: Migration, Circassian, Kosovo, the Balkans, Rumelia, the Ottoman Empire

\section{Giriş}

Kuzey Kafkasya'nın otokton halklarından olan ve Adıge ${ }^{1}$ topluluklarından oluşan Çerkeslerin Kafkasya'daki varlıkları milattan önceki dönemlere kadar uzanmaktadır. Çerkes adının da Antik Çă̆da Çerkesya'da yaşamış olan Kerketlerin (Cercetae) isminden türemiş olduğu düşünülmektedir². Çerkes adı ayrıca daha geniş bir anlamda, Adigelerle birlikte Vubıh (Ubıh) ve Abhazları (Abaza) isimlendirmede kullanıldı̆̆ı gibi, tüm Kafkasya halklarını ifade etmek için de kullanılmaktadır.

1 Adıgeler Abzeh, Hatukay, Kemirguyev (Temirgoy-Çemguy), Adamey, Bjeduğ (Yegerkhoy-Kiray), Mahuş (Makhoş), Şapsı̆g, Natukhaç, Jane, Kabardey ve Besleney (Besniy) kabilelerinden oluşmaktadır. Yalçın Kaya, Çerkesler-I- Tarih-Mitoloji-Gelenek, Dahi Yayıncılık, İstanbul 2015, s. 15.

2 Kaya, age., s. 18-19.

Belleten, Aralık 2021, Cilt: 85/Sayı: 304; 991-1024 
Çerkesler Kuzeybatı Kafkas dillerini konuşmaktadırlar ve anavatanları Çerkesya’dır. Çerkesya, Kafkasya'nın kuzeybatısında, Kafkas Dağları, Kuban Nehri ve Karadeniz arasinda yer alan bir bölgedir³.

Ulusal kimlikleri XIX. yüzyılda oluşmaya başlayan Çerkesler, tarihsel süreç içerisinde kabileler halinde örgütlenmişler ve feodal bir toplumsal yapı meydana getirmişlerdir. Toplum prensler, soylular, hür köylüler ve serfler gibi sinıflara ayrılmıştır ${ }^{4}$.

Çerkesler eski çağlarda, habze adı verilen geleneklerine bağlı olarak, Animizm'e ve büyüye inanmışlardır. VI. yüzyıldan itibaren de Hıristiyanlı̆̆ benimsemeye başlamışlardır ${ }^{5}$. Osmanlı Devleti'nin XVI. yüzyılın başlarında Kafkasya'nın batısında hâkimiyet kurmasından sonra ise Çerkesler arasında İslamiyet yayılmaya başlamıştır. Çerkeslerin büyük çoğunluğu XVIII. ve XIX. yüzyıllarda İslamiyet’i kabul etmiştir. Bu durumun ortaya çımasında özellikle kuzeybatıdan gelen Nogay din adamlarının çalışmaları ve Dağıstan'daki Müridizm hareketi etkili olmuştur.

XVIII. ve XIX. yüzyıllar aynı zamanda Rusya'nın Kafkasya'yı hâkimiyeti altına almaya yönelik çabalarını yoğunlaştırmaya başladığı ve Çerkeslerin Osmanlı Devleti’ne göç etmelerine zemin hazırlayan gelişmelerin ortaya çıktı̆̆ bir dönem olmuştur. Çerkes göçleri Kırım Savaşı’ndan sonra başlamış ve 1862-1865 yılları arasında yoğunlaşmışıı ${ }^{6}$. Çerkesler Osmanlı Devleti tarafindan Rumeli'ye, Anadolu'ya ve Ortadoğu'ya yerleştirilmişlerdir.

Çerkeslerin 1864-1865 yıllarında Rumeli'de iskân edildiği yerlerden birisi de Kosova'dır. Kosova'ya yapılan Çerkes göçü ve iskânı; Kosova tarihi, Çerkes tarihi ve Osmanlı tarihi açısından önem taşıyan bir konudur. Ancak bu konuda Türkiye'de ve Türkiye dışında yeterli araştırma yapılmamıştır. Çalışmanın amacı, bu alandaki eksikliğin giderilmesine katkıda bulunmaktır.

Çalışma hazırlanırken Kosova'nın tarihî sınırları esas alınmıştır. Gumhurbaşkanlığı Devlet Arşivleri Başkanlığı Osmanlı Arşivindeki belgelerden, Kosova vilâyeti

3 Fabio L. Grassi, Yeni Bir Vatan. Çerkeslerin Osmanl Imparatorluğu'na Zorunlu Göçü (1864), çev. Birgül Göker Perdisa, 2. baskı, Tarihçi Kitabevi, İstanbul 2017, s. 21.

4 Kemal H. Karpat, Osmanlı'dan Günümüze Etnik Yapılanma ve Göçler, Timaş Yayınları, İstanbul 2010, s. 164 .

5 Kaya, age., s. 65, 73.

6 Kemal H. Karpat, "Avrupalı Egemenliğinde Müslümanların Konumu Çerkeslerin Sürgünü ve Suriye'deki İskanı”, Çerkeslerin Sürgünü 21 Mayns 1864 (Teblĭgler, Belgeler, Makaleler), Kafkas Derneği Yayıları, Ankara 2001, s. 82-84. 
salnâmeleri ve devlet salnâmelerinden, dönemin gazetelerinden ve konuyla ilgili Türkçe ve yabancı dillerde yazılan eserlerden faydalanılmıştır.

Makalede, 1864-1865 yıllarında Kosova'ya yapılan Çerkes göçünün sebepleri, göçün güzergâhı, göç ve iskân sırasında karşılaşılan sorunlar ve bu sorunların çözümü için izlenen politikalar, Kosova'ya göç eden Çerkeslerin sayısı ve yerleştikleri yerler, Kosova Çerkeslerine yapılan yardımlar, Çerkeslerin Kosova'ya uyum süreçleri ve Kosova'dan ayrılışları incelenmiştir. Kosova'ya göç eden Çerkeslerin sayısı konusunda literatürde yer almayan bazı bilgiler verilmiştir. Yine ilk defa, 1865 yllında da Kosova'ya Çerkes göçünün devam ettiğini ortaya koyan veriler neşredilmiştir. Ayrıca, taranan Türkçe ve yabancı dillerdeki eserlerde yer almayan, arşiv belgelerinden tespit edilen ve ilk defa yayınlanmış olacağı düşünülen 3 Çerkes köyünün adı paylaşılmıştır. Yer isimleriyle ilgili olarak bunun haricinde, Türkçe çalışmalarda bahsedilmeyen, Çerkeslerin Kosova'da yerleştiği 16 köyün, 1 kasabanın ve 1 şehrin isimleri de belirtilmiştir. Bu hususların dışında Marc Pinson'un Osmanlı Devleti'nin Çerkeslerin Rumeli'ye iskânı için yeterli hazırlık yapmadığına ilişkin iddiasının, Kosova özelinde gerçeği yansıtmadığını gösteren bilgiler sunulmuştur.

\section{1. Çerkeslerin Osmanlı Devleti'ne Göç Etmelerini Hazırlayan Gelişmeler}

Kafkasya sahip olduğu jeopolitik konumu sebebiyle tarih boyunca büyük devletlerin mücadele alanı olmuştur. Bölgeyi hâkimiyeti altına almak isteyen güçler arasında Osmanlı Devleti de yer almıştır. 1475 yılında Kırım'ı alarak Kafkasya’yla komşu olan Osmanlı Devleti, 21 Temmuz 1774’te imzalanan Küçük Kaynarca Antlaşması'yla Kırım'ı kaybettikten sonra Kafkasya bölgesine daha fazla önem vermeye ve Çerkeslerle yakınlaşmaya başlamıştır. Osmanlı Devleti'nin önündeki en büyük engel Rusya olmuştur. Osmanlı Devleti, 1828-1829 Savaşı'nda Rusya'ya mağlup olduktan sonra 14 Eylül 1829 tarihinde imzalanan Edirne Antlaşması’yla Çerkesya üzerindeki haklarından vazgeçmiştir?

XVI. yüzyıldan itibaren Kafkasya'yı hâkimiyeti altına almaya yönelik bir politika izlemeye başlayan Rusya ise 1801'de Gürcistan'1, 1810'da Abhazya'yı, 1822'de Kabardey bölgesini ve 1859'da Dağıstan ile Çeçenistan'ı ele geçirmiştir. Bu süreçte Çerkes tarihi açısından önemli sonuçlar doğuracak olan Kırım Savaşı (1853-1856) yaşanmıştır. Bu savaş, Çerkeslerin Kuzey Kafkasya'dan sürülmelerinde etkili ol-

7 İzzet Aydemir, Göç: Kuzey Kafkasya’hlarn Göç Tarihi, Gelişim Matbaası, Ankara 1988, s. 9-15.

Belleten, Aralık 2021, Cilt: 85/Sayı: 304; 991-1024 
muştur. Çerkesler savaş sırasında müttefik devletlere bekledikleri desteği vermemişlerdir. Savaştan sonra 25 Şubat 1856'da toplanan Paris Barış Konferansı'nda Kafkasya ve Çerkes sorunu da gündeme gelmiştir. İngiliz ve Türk diplomatlar, Edirne Antlaşması'nın tekrar ele alınmasını ve İngiltere ile Osmanlı Devleti himayesinde bir Çerkes devleti kurulmasını Rusya'ya kabul ettirmeye çalışmışlardır. Bu devletin kurulmasıyla Rus sınırlarının güneye doğru genişlemesinin önlenmesi amaçlanmıştır. Hindistan'a giden ticaret yolunu güvence altına almak ve Kafkasya'yla ticaretini geliştirmek isteyen İngiltere'nin Kafkasya'daki planlarından rahatsız olan Fransa, İngiltere'ye ve Osmanlı Devleti'ne destek vermemiştir. Fransa'nın bu politikasından yararlanan Rusya, İngiltere'nin ve Osmanlı Devleti'nin Çerkeslerle ilgili isteklerini kabul etmemiştir.

Osmanlı Devleti ve İngiltere, 30 Mart 1856'da Paris Barış Antlaşması'nın imzalanmasından sonra da Çerkesya'da Rusya aleyhinde faaliyetlerde bulunmaya devam etmiştir ${ }^{8}$. Rusya ise savaş sırasında, Çerkeslerin Kafkasya ve Karadeniz bölgesindeki iletişim hatları için ciddi bir tehdit olduğunu anlamıştır. Rus yönetimi, Kırım Savaşı’nın sona ermesiyle birlikte Kafkasya'daki Müslümanların gücünü tamamen kırmaya karar vermiş ${ }^{9}$ ve aralarında Çerkeslerin de bulunduğu Müslümanları başka bölgelere ve Osmanlı Devleti topraklarına göçe zorlamaya başlamıştır.

Osmanlı Devleti Çerkes muhacirleri kabul etmiştir. Osmanlı yönetimi, ülkedeki Müslüman nüfusu çoğaltmak, tarımsal üretimi arttırmak ve orduyu güçlendirmek için Çerkeslerden faydalanmak istemiştir. Çerkesler Kafkasya'yı iyi tanıyorlardı ve Ruslarla savaşta tecrübeliydiler ${ }^{10}$. Osmanlı Devleti, daha önce Rusya'nın Kırım'dan göçe zorladığı Tatarları yerleştirdiği gibi, Çerkesleri de Rumeli'ye iskân etmeyi planlamıştır ${ }^{11}$.

\section{2. Ģerkeslerin Osmanlı Devleti'ne Göç Etmeleri}

Osmanlı Devleti’ne ilk Çerkes göçü, Kırım Tatarlarının da Osmanlı topraklarına göç ettikleri bir sırada, 1856 yllında başlamışıır². 1856 yllından sonra muhâ-

8 Aliy Kasumov-Hasan Kasumov, Çerkes Soykırmm: Çerkeslerin XIX. Yüzyıl Kurtuluş Savaşı Tarihi, çev. Orhan Uravelli, 1. baskı, Kafkas Derneği, Ankara 1995, s. 199-213.

9 Karpat, agm., s. 83.

10 Walter Richmond, Çerkes Soykrrmı, çev. Erdoğan Boz, Koyusiyah Yayıncılık, Ankara 2018, s. 131132.

11 Yediç Baturay Özbek, Çerkes Tarihi Kronolojisi, Ankara 1991, s. 129.

12 Karpat, agm., s. 84. 
cirlerin sayısı giderek artmıştır. Bunun üzerine Osmanlı yönetimi, 1859 yılında Rusya'ya gelişmelerden duyduğu rahatsızlığı bildirmiş ve 1860 yılında Rusya ile Osmanlı Devleti arasında muhacirlerin küçük kafileler halinde gönderilmesi konusunda anlaşma sağlanmıştır ${ }^{13}$.

Rusya Çerkesler üzerindeki baskısını 1861 yılından itibaren daha da arttırmaya başlamıştır. Çar II. Alexander, eylül ayının sonunda, Çerkeslerden Kuban bölgesine yerleşmelerini ya da Osmanlı Devleti’ne göç etmelerini istemiştir. Çerkeslerin büyük kısmı bu isteği kabul etmemiştir ${ }^{14}$. Bunun üzerine Rus ordusu, 1861 yılı Kasım ayı başlarında Çerkeslerin yaşadığı bölgelere saldırmış ${ }^{15}$ ve halkı Osmanlı Devleti topraklarına sürmeye başlamıştır ${ }^{16}$. Böylece kitlesel bir göç başlamıştır ${ }^{17}$. Bununla birlikte Çerkeslerin önemli bir kısmı Rus ordusuna karşı direnişe geçmiştir. Rusya, göçü hızlandırmak için 10 Mayıs 1862'de bir komisyon kurmuş ve komisyonun aldığı kararlarla zorunlu göç resmîleşmiştir ${ }^{18}$.

Rus-Çerkes Savaşı'nın başlamasından sonra, savaşı Rusların kazanacağını düşünen Osmanlı Devleti, Çerkesleri göçe teşvik etmeye başlamıştır. Osmanlı Devleti’nin elçileri, 1863 yılında Çerkeslere Osmanlı hükûmetinin kendileri için daha iyi yaşam koşulları sağlayacağını ve evler inşa edeceğini vadetmişlerdir ${ }^{19}$.

Kafkasya'da yaşanan gelişmeleri İngiltere ve Fransa da yakından takip etmiştir. Çerkeslerin vatanlarını terk etmesi durumunda Kafkasya'da Rusya'nın düşmanlarının azalacă̆ını düşünen İngiltere ve Fransa, Çerkeslerin göç etmesine karşı çımıştır ${ }^{20}$.

13 Kasumov, age., s. 257-258.

14 Grassi, age., s. 70.

15 Richmond, age., s. 101.

16 Kasumov, age., s. 243.

17 Karpat, agm., s. 84.

18 Ufuk Erdem, Osmanl'dan Cumhuriyet'e Muhacir Komisyonlan ve Faaliyetleri (1860-1923), TTK Yayınları, Ankara 2018, s. 94.

19 Grassi, age., s. 85. Walter Richmond, Türklerin 1863 yılı sonbaharına kadar olan dönemde Çerkeslere ülkelerinde kalıp savaşmalarını isteyen ve uluslararası yardım sözü veren bildiriler gönderdikleri bilgisini vermektedir. Richmond, age., s. 120.

20 Kasumov, age., s. 259. Fabio L. Grassi’ye göre, Rusya’nın Kafkasya’yı işgalinin önüne geçilmesinin zor olduğunu ve göç eden Çerkesler vasıtasıyla Osmanlı ordusunun güçlenerek Rus ordusuna karşı daha dayanıklı hale geleceğini düşünen İngiltere'nin ve Fransa'nın bölgedeki ajanları, Çerkesleri göçe teşvik etmeye çalışmışlardır. Grassi, age., s. 86. 
Rusya 1863 yllında da Çerkesya'daki işgallerine devam etmiştir. Rus ordusu, 1863 yılının sonlarında Abzehlerin ve Şapsığların topraklarını ele geçirmiş ve 1864 yılında, direnmeye devam eden son topluluk olan Vubıhlara boyun eğdirmiştir ${ }^{21}$. Son direnişin kırılmasından sonra 1864 yılı Mayıs ayında Kuzeybatı Kafkasya'nın tamamı Rusya tarafindan işgal edilmiş ve bölgeden göçlerin en yoğun olduğu dönem başlamıştı²2. Abzeh, Şapsı̆̆, Kemirguyev, Mahuş, Natukhay, Jane, Besleney ve Bjeduğların büyük çoğunluğu, Kabardeylerin az bir kısmı, Abhazların yarıya yakını ve Vubıhların tamamı Osmanlı Devleti’ne göç etmiştir23.

1864 yılında Osmanlı Devleti’ne göç eden Çerkeslerin sayısı konusunda dönemin gazetelerinde farklı bilgiler yer almaktadı2 ${ }^{24}$. Konuyla ilgili yapılan bazı çalışmalarda ise 250.000 ile 750.000 arasında sayllar verilmektedir² .

Osmanlı Devleti’ne göç eden Çerkeslerin büyük bir kısmı gemilerle Karadeniz üzerinden Anadolu'ya ve Balkanlar'a taşınmıştır. Osmanlı Devleti donanmadan büyük gemiler ve vapurlar temin etmiştir. Ayrıca tüccar gemileri kiralanmıştı²6. Taşıma işi daha çok, Rus ve Türk gemileriyle gerçekleştirilmiştir ${ }^{27}$. Çerkesler Kafkasya ve Kırım kıyılarındaki limanlardan alınarak Balkan Yarımadası ve Anadolu kıyılarındaki limanlara götürülmüşlerdir ${ }^{28}$. Muhacirler Anadolu kıyılarındaki limanlara ulaştıktan sonra bir kısmı tekrar deniz yoluyla Rumeli'deki ve Marmara Denizi’ndeki limanlara gönderilmiştir. ${ }^{29}$.

21 Kadir Natho, Kafkasya'da ve Kafkasya Dışındaki Çerkesler, çev. Ömer Aytek Kurmel, Kaf-Dav Yayınları, Ankara 2009, s. 268.

22 Nihat Berzeg, Çerkesler Kafkas Sürgünü: Vatansız Burakulan Bir Halk, Chiviyazıları Yayınevi, İstanbul 2006, s. 219.

23 Aydemir, age., s. 94.

24 Rûznâme-i Cerîde-i Havâdis, 10 Ağustos 1864, No: 928, s. 2-3; Takvîm-i Vekâyi, 15 Haziran 1865, No: 804, s. 3.

25 Kasumov, age., s. 254; Richmond, age., s. 122; Aydemir, age., s. 111; Berzeg, age., s. 234.

26 Rûznâme-i Cerî̀e-i Havâdis, 10 Ağustos 1864, No: 928, s. 2-3.

27 Richmond, age., s. 118-119. Kars, Malakof, Hümâ-yı Tevfik, Tuna, Tâif, Mecîdiyye ve Eser-i Cedîd adlı vapurlar ile Keyvân-ı Bahrî Fırkateyni muhacirlerin taşınmasında kullanılan gemiler arasında yer almıştır. Necdet Hayta-Uğur Ünal, Osmanh Askerî Gazetesi Cerîde-i Askeriyye 1-30, Berikan Yayınevi, Ankara 2010, s. 59, 93, 157, 186, 206, 233, 260-261, 275, 336, 361-362, 389, 409-410, 431-432, 454, 478.

28 Aydemir, age., s. 95.

29 Trabzon, Samsun ve Batum limanlarından alınan muhacirler Varna, Selanik, Gelibolu, Mudanya, Tekirdağ, İzmit, Gemlik, Bandırma ve Silivri'ye taşınmışlardır. Hayta-Ünal, age., s. 93, 157, 206, 260, 336, 361-362, 389, 409-410, 431, 454, 478. 
Rusya 1864 yılının Aralık ayında toplu göçleri durdurma kararı almıştır. 1867 y1lında da hükûmetin 1862 yılında aldığı Batı Kafkasya halkına göç etme izni veren kararı iptal edilmiştir ${ }^{30}$. Ancak göçler tamamen sona ermemiştir.

Çerkes göçlerinin ikinci dönemi olarak kabul edilen 1862-1870 yıllarında 1.200.000-2.000.000 arasında muhacir Osmanlı Devleti'ne göç etmiştir ${ }^{31}$. Göçler 1870 yllından sonra tekrar başlamıştır. 1877-1878 Osmanlı-Rus Savaşı sırasında ve sonrasında Osmanlı Devleti'ne göç eden topluluklar arasında Çerkesler de yer almıştır ${ }^{32}$.

\section{3. Çerkeslerin 1864 ve 1865 Ylllarında Kosova'ya Göç Etmeleri ve İskân Edilmeleri}

\section{a. Çerkeslerin Rumeli’ye İskân Edilmeleri}

Osmanlı Devleti, 1853-1876 yılları arasında yaşanan Tatar ve Çerkes göçlerinde Balkanlar'ı ikinci önemli iskân bölgesi olarak belirlemiştir ${ }^{33}$. Çerkesler 1862 ve 1863 ylllarında Niş ve Ürgüp (Prokuple) civarına yerleştirilmişlerdir ${ }^{34}$. Abzehler 1863 yılı Mayıs ayında Rumeli'ye göç etmeye başlamışlar ve günümüzdeki Bulgaristan topraklarına iskân edilmişlerdir ${ }^{35}$.

Rumeli'ye Çerkes göçleri 1864 ylının başlarında da devam etmiştir ${ }^{36}$. Rus ordusunun Kafkasya'daki savaşı kazanmasından sonra mayıs ayından itibaren Balkanlar'a doğru çok daha büyük bir göç başlamıştır. Osmanlı Devleti, bu süreçte muhacirlerin Rumeli'de iskân edileceği bölgelerin ve iskân yerlerine taşınacakları yolların belirlenmesi sorunuyla karşılaşmıştır. Bu konuda farklı görüşler ortaya çımışıtır. Meselâ, Bosna ve Hersek Askerî Fırkası Kumandanı Ferik Ömer Fevzi Paşa 1 Mayıs 1864 tarihli arîzasında iskân için iki bölge önermiştir. Bunlardan birincisi Yenipazar'dan Sirbistan sinırına uzanan yol üzerindeki uygun mahallerdi. İkincisi ise Karadağlıların saldırılarına ve Hersek'teki isyancılara karşı Hersek’teki asi nahiyeleri ikiye bölen ve Mostar-Nevesin-Gaçka-Duga Boğazı-Nikşik hattında

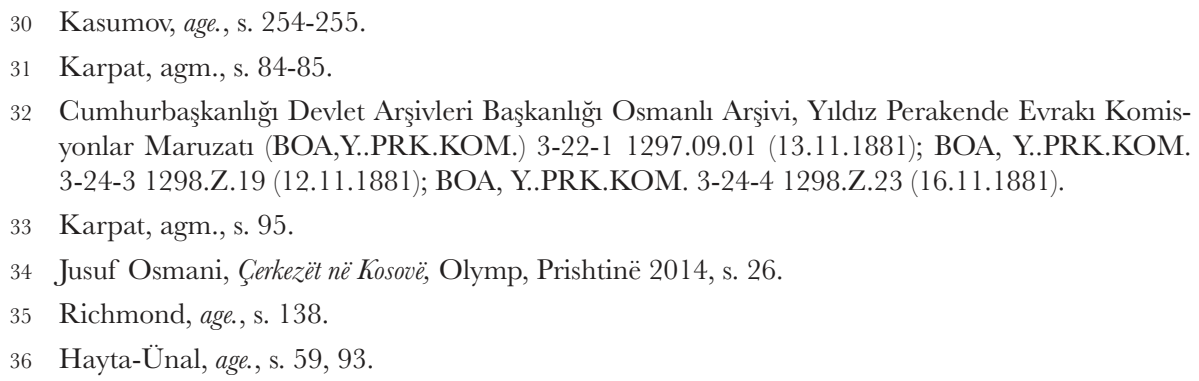

Belleten, Aralık 2021, Cilt: 85/Say1: 304; 991-1024 
bulunan cadde üzerindeki Duga Boğazı ve diğer önemli geçitlerdi. Ferik Ömer Fevzi Paşa, arîzasında ayrıca, muhacirlerin Rumeli’ye iskân edilmesiyle görevli olan Nusret Paşa'yı Hersek'te görevlendirilmemek için Çerkeslerin Hersek'e iskânını Bâb-ı Âli’ye çok masraflı olarak göstermekle ve bu yolla kendi düşüncesini hükûmete kabul ettirmekle suçlamıştır.

Ferik Ömer Fevzi Paşa, söz konusu arîzasında muhacirlerin taşınmasında kullanılacak yollar konusuna da değinerek Tuna Nehri yoluyla getirilmeleri halinde muhacirlerin perişan olabileceklerini ve kayıplar verebileceklerini, buna karşın deniz yoluyla Klik İskelesi'ne gönderilmeleri halinde sıkıntı çekmeyeceklerini ve bu yolun daha az masraflı olacağını belirtmiştir ${ }^{37}$.

Marc Pinson, Osmanlı Devleti'nin Çerkeslerin Rumeli'ye iskânı için yeterli hazırlık yapmadığını, muhacirlerin dağıtım ve iskânlarının daha çok, taşrada duruma göre alınan kararlarla gerçekleştirildiğini ifade etmektedir ${ }^{38}$. Ancak Osmanlı Devleti Çerkeslerin Kosova'ya iskânı için ciddi bir hazırlık yapmışır. Bununla ilgili bilgiler, çalışmanın Çerkeslerin Kosova'ya göç etmelerinin ve iskân edilmelerinin anlatıldığı kısmında verilmiştir.

Osmanlı Devleti, Çerkesleri Anadolu'ya genel olarak dağınık bir şekilde iskân ederken, Balkanlar'da mümkün olduğunca toplu bir şekilde yerleştirmeye çalışmış$\operatorname{tır}^{39}$. Çerkesler, Ruslara ve Sırplara karşı savunma hattı oluşturma düşüncesiyle, daha çok, Osmanlı-Sırp sınırındaki ve Dobruca'ya kadar Tuna Nehri civarındaki stratejik yerlere iskân edilmişlerdir ${ }^{40}$. Muhacirler bu süreçte ilk önce, daha önceki Tatar göçlerinde olduğu gibi, Karadeniz kıyısındaki limanlardan iç bölgelerdeki ikinci dağıtım ve yerleşim yerlerine gönderilmişlerdir ${ }^{41}$. Nusret Paşa, muhacirlerin Tuna Nehri üzerindeki sevk noktalarına taşınması için Avusturya hükûmetiyle anlaşarak Tuna Nehri'ndeki gemileri kiralamıştır².

37 BOA, Taşra Evrakı-Bosna Müfettişliği Evrakı (TŞRBNM.) 19-13-1, 2 1280.Za.24 (01.05.1864).

38 Marc Pinson, "Kırım Savaşı’ndan Sonra Osmanlılar Tarafindan Çerkeslerin Rumeli’ne İskanı", Çerkeslerin Sürgünü 21 Mayıs 1864 (Tebliğler, Belgeler, Makaleler), Kafkas Derneği Yayınları, Ankara 2001, s. 65-66.

39 Yalçın Kaya, Çerkesler-III-Sürgün ve Soykırm, 1. Baskı, Dahi Yayıncılık, İstanbul 2015, s. 513.

40 Karpat, agm., s. 85. Kadir Natho, Çerkeslerin Mithat Paşa’nın hazırladığı projeye göre Tuna Nehri’nin ağzı ile Bosna-Hersek arasındaki topraklara yerleştirildiğini belirtmektedir. Natho, age., s. 293.

41 Pinson, agm., s. 55.

42 Aydemir, age., s. 137. 
Muhacirlerin Rumeli'ye dağıtılmasına haziran ayından önce başlanılmıştır ${ }^{43}$. Köstence Limanı merkez olarak kullanılmıştır. Haziran ayında aralarında çiçek hastalığına yakalananların da bulunduğu 35.000 Çerkes, Köstence Limanı'nda toplanmışıı ${ }^{44}$. Köstence ve Varna limanlarına gelen 60.000 kadar muhacir Tuna Nehri'ne yollanmıştır ${ }^{45}$. Köstence Limanı'na çıkanlar Tatar göçlerinden sonra tamamlanan Köstence-Cerna Voda demiryoluyla Tuna Nehri kıyısındaki Cerna Voda'ya gönderilmişlerdir. Muhacirler haziran ayı sonlarında da Cerna Voda'dan gemilerle yine Tuna Nehri kıyısındaki Lom'a taşınmışlardır. Lom’da 60.000 kişi toplanmıştır ${ }^{46}$. Muhacirler buradan da iskân edilmek üzere farklı bölgelere gönderilmişlerdir ${ }^{47}$.

Çerkesler Tuna Nehri’ndeki yolculukları sırasında çok fazla kayıp vermişlerdir. Bosna ve Hersek Askerî Fırkası Kumandanı Ferik Ömer Fevzi Paşa, muhacirlerin Tuna Nehri’nden taşınmaması konusundaki uyarısında haklı çıkmıştır. Muhacirleri gemileriyle taşıyan Avusturyalı Kaptan Kanitz, birçok yerin Çerkes mezarlıklarıyla dolduğunu belirtmektedir ${ }^{48}$. Mavnalarla konvoylar halinde yolculuk yapan muhacirler çok sayıda fâcia yaşamışlardır ${ }^{49}$.

Rumeli'ye iskân edilen Çerkeslerin sayısı 1865 yılının başlarına kadar geçen sürede daha da artmıştır. Tercümân-ı Ahvâl gazetesinin 26 Şubat 1865 tarihli sayısında çıkan bir haberde, tutulan defterler dikkate alınarak, bu konuda detaylı bilgi verilmiştir. Habere göre, son bir yıl içinde Rumeli'ye 70.000 hâne Çerkes yerleştirilmiştir. Bu hânelerden 5.000-6.000 kadarı Burgaz'dan Edirne'ye gönderilerek burada iskân edilmiştir. 14.000’i Varna'dan Rusçuk'a ve Tuna eyaletinin diğer mevkilerine gönderilmiştir. 12.000 hâne de Niş ve Sofya sancaklarına iskân edilmiştir. Tuna Nehri yoluyla gelerek nehir boyunda ve Sırbistan sınırı üzerinde yerleştirilen muhacirlerin sayısı 150.000 ile 250.000 arasındadır $^{50}$.

Pinson, agm., s. 55.

Pinson, agm., s. 56.

Özbek, age., s. 156.
Rûznâme-i Cerîde-i Havâdis, 7 Haziran 1864, No: 884, s. 1.

BOA, Sadâret Mektûbî Mühimme Kalemi (A. \}MKT.MHM.) 305-94-1 1281.S.10 (15.07.1864).

Takoîm-i Vekâyi, 18 Temmuz 1864, No: 757, s. 1; Pinson, agm., s. 56-57.

Muhittin Kandur, Bir Balkan Öyküsü, çev. Özge Öztürk, Apra Yayıncılık, İstanbul 2017, s. 11.

Tercümân-ı Ahvâl, 26 Şubat 1865, No: 610, s. 2. Jusuf Osmani, Rumeli’ye 40.000 Çerkes ailesinin yerleştirildiğini ifade etmektedir. Osmani, age., s. 20. 
1864 yılından önce ve sonra yaşanan göçler de dikkate alındığında, Rumeli’ye iskân edilen Çerkeslerin sayısı 400.000’i geçmektedir ${ }^{51}$.

\section{b. XIX. Yüzyılın İkinci Yarısında Kosova'nın İdari Yapısı}

Günümüzde kuzeyinden ve doğusundan Sirbistan, güneydoğusundan Kuzey Makedonya, güneybatısından Arnavutluk ve batısından Karadağ ile çevrili olan Kosova Cumhuriyeti, 10.908 km² yüzölçümüne sahiptir. Ülkenin bugünkü sınırları, Kosova'nın tarihî sınırlarına yakındır. Kosova'nın kesin siyasî ve coğrafî sınırları, ilk defa 1945 yılında çizilmiştir. Daha önce, farklı devletler ve idarî birimler arasında bölünerek yönetilmiş, tarihsel bütünlüğü olmayan bir coğrafyaydı ${ }^{52}$.

28 Haziran 1389 tarihinde yaşanan I. Kosova Savaş1, Kosova tarihindeki önemli kırılma noktalarından birisidir. Osmanlı Devleti bu savaştan sonra Kosova'da hâkimiyet kurmaya başlamıştır. Kosova’nın tamamı 1455 yılında Osmanlı Devleti’ne bağlanmıştır. Kosova Ovası Fatih Sultan Mehmed döneminde, Rumeli beylerbeyliğine bağlı olan Vulçıtrın ve Üsküp sancaklarının sınırlarına dahil edilmiştir. XVII. yüzyılın başlarında ise Bosna ve Rumeli eyaletlerinin sınırları içinde yer almıştır ${ }^{53}$.

Kosova'daki idarî yapı XIX. yüzyılda sık sık değişmiştir. 1844 yılında kurulan Üsküp eyaletine Prizren ve Priştine sancakları da dahil edilmiştir ${ }^{54}$. Bu sancaklar hemen hemen Kosova'nın tamamını içine alıyordu. Prizren sancağı, 1863 yılında Prizren, İvranye, Yakova, Altunili, İpek, Kalkandelen, Kumanova, Priştine, Gilan (Neveberde), Vulçıtrın ve Gora kazalarından oluşuyordu. Kaçanik, Üsküp sancağına bağhı bir nahiyeydi ${ }^{55}$. 1864 yılında Kumanova ve İvranye ${ }^{56}, 1865$ yılında da Gora, Prizren sancağının kazaları arasında yer almamıştır ${ }^{57}$.

Tanzimat Dönemindeki yenileşme hareketleri çerçevesinde 1864 yılında Vilâyet Nizâmnâmesi’nin yayınlanmasından sonra Üsküp eyaleti vilâyete dönüştürülmüş

51 Karpat, agm., s. 85.

52 Noel Malcolm, Kosova: Balkanlan Anlamak İ̧̧in, çev. Özden Arıkan, Sabah Kitapları, İstanbul 1999, s. 18-19.

53 Münir Aktepe, "Kosova", Türkiye Diyanet Vakfi İslam Ansiklopedisi, C 26, Türkiye Diyanet Vakfi İslam Araştırmaları Merkezi, Ankara 2002, s. 217.

54 Yakup Ahbab, “Tanzimat Dönemi İdari Düzenlemelerinin Üsküp Eyaleti’nde Tatbiki”, Türkiyat Mecmuast, 25/2 (2015), s. 6, 15.

55 Salnâme-i Devlet-i Aliyye-i Osmaniyye, 1280, Defa 18, s. 159-160.

56 Salnâme-i Devlet-i Aliyye-i Osmaniyye, 1281, Defa 19, s. 164.

57 Salnâme-i Devlet-i Aliyye-i Osmaniyye, 1282, Defa 20, s. 152. 
ve 1868 yılında yeni yönetim şekli uygulanmaya başlanmıştır. Prizren sancağı 1868 yılında yayınlanan devlet salnâmesine Üsküp vilâyetinin bir sancağı olarak kaydedilmiştir ${ }^{58}$. Ancak, aynı yıl Üsküp vilâyetinin İşkodra vilâyetine dahil edilmesine karar verilmiştir ${ }^{59}$. Prizren sancağı da İşkodra vilâyetine bağlanmıştır ${ }^{60}$.

1869 ve 1870 yıllarının devlet salnâmelerinde İşkodra vilâyetine bağlı bir sancak olarak görülen Prizren'in ${ }^{61}$ bu statüsü kalıcı olmamıştır. Kısa bir süre sonra Prizren, Debre ve Üsküp sancaklarından oluşan Prizren vilâyeti kurulmuştur. Vilâyete ilişkin bilgiler 1871 yllında çıkarılan devlet salnâmesinde yazılmıştı́r2 1872 yllında Prizren vilâyetinin sancakları arasında Niş de yer almışır ${ }^{63}$. Ancak Prizren vilâyeti uzun ömürlü olmamış ve 1874 yllında kaldırılmıştır ${ }^{64}$. Prizren sancağı yeni dönemde Manastır vilâyetine bağlanmıştır ${ }^{65}$.

Kosova'daki idarî yapı 1877 yılında, bölgenin adını taşıyan Kosova vilâyetinin kurulmasıyla bir kez daha değişmiş̧ir. Kosova vilâyeti, 1877 yllında Priştine, Prizren, Üsküp, Niş, Şehirköy, Yenipazar ve Debre sancaklarına ayrılmışır. 1877-1878 Osmanlı-Rus Savaşı'ndan sonra Niş ve Şehirköy sancaklarının Osmanlı Devleti’nin hâkimiyetinden çıkması sonucunda sancak sayısı 5'e düşmüştür. Vilâyetin mülkî yapısında 1878 yılından sonraki dönemde de zaman zaman değişiklikler yapılmiştı ${ }^{66}$.

58 Salnâme-i Devlet-i Aliyye-i Osmaniyye, 1285, Defa 23, s. 175.

59 Ahbab, agm., s. 21.

60 Salnâme-i Devlet-i Aliyye-i Osmaniyye, 1286, Defa 24, s. 132.

61 Salnâme-i Devlet-i Aliyye-i Osmaniyye, 1286, Defa 24, s. 132; Salnâme-i Devlet-i Aliyye-i Osmaniyye, 1287, Defa 25, s. 216.

62 Salnâme-i Devlet-i Aliyye-i Osmaniyye, 1288, Defa 26, s. 242.

63 Salnâme-i Devlet-i Aliyye-i Osmaniyye, 1289, Defa 27, s. 245.

64 Aşkın Koyuncu, “Tuna Vilâyeti’nde Nüfus ve Demografi (1864-1877)”, Turkish Studies, 9/4 (2014), s. 679 .

65 Salnâme-i Devlet-i Aliyye-i Osmaniyye, 1292, Defa 30, s. 246; Salnâme-i Devlet-i Aliyye-i Osmaniyye, 1293 , Defa 31, s. 445-446; Salnâme-i Devlet-i Aliyye-i Osmaniyye, 1294, Defa 32, s. 445-446.

66 Mucize Ünlü, Kosova Vilayeti, Gece Kitaplı̆̆ı, Ankara 2014, s. 57 vd. Şemseddin Sâmi, Kosova vilâyetinin Osmanlı-Rus Savaşı’nın başlamasından önce kurulduğunu, merkezinin Sofya olduğunu, Niş ve Priştine bölgelerini de içine aldığını ve merkezinin savaştan sonra Priştine’ye taşındığını belirtmektedir. Şemseddin Sâmi, Kâmûsül-alâm, G V, Mihran Matbaası, İstanbul 1314, s. 3748. 1878 yılında basılan devlet salnâmesine göre, vilâyet Prizren, Üsküp ve Yenipazar sancaklarına ayrılmıştı. Salnâme-i Devlet-i Aliyye-i Osmaniyye, 1295, Defa 33, s. 199-201. 1879 yılına ait Kosova Vilâyet Salnâmesi'nde, sancaklar arasında Debre ve Priştine de görülmektedir. Priştine sancağı, vilâyet merkezi olarak yazılmıştır. Salnâme-i Vilâyet-i Kosova, 1296, Defa 1, Priştine 1296, s. 118123.

Belleten, Aralık 2021, Cilt: 85/Sayı: 304; 991-1024 


\section{c. Çerkeslerin Kosova'ya Göç Etmeleri ve İskân Edilmeleri}

Kosova'nın nüfusu XIX. yüzyılda, daha önceki dönemlerde olduğu gibi, kozmopolit bir yapıdaydı. Rumeli'ye gelen Çerkeslerin bir kısmının Kosova'ya iskân edilmesine karar verildiği dönemde bölgede Sırp, Yahudi, Ortodoks Valah, Ortodoks Çingene, Ortodoks Arnavut ve Katolik Arnavut gibi gayrimüslim topluluklar ile Arnavut, Çingene, Türk ve Slavlardan oluşan Müslüman nüfus yaşıyordu. Gayrimüslim nüfusun büyük kısmı Sırp'tı. Müslüman nüfusun çoğunluğu ise Arnavut'tu ${ }^{67}$. Saraybosna'da görev yapan Rus Konsolosu Alexander Giljferding'in 1857 yllında paylaştı̆̆ bilgilere göre, Prizren'de 3.000 hâne Müslüman, 900 hâne Ortodoks Sırp ve 100 hâne Katolik yaşamaktaydı. Müslüman nüfusun oranı \% $75^{\prime} \mathrm{ti}^{68}$.

Kosova'ya Çerkes göçü 1864 yılında başlamıştır. Ancak bazı kaynaklarda bölgeye 1864 yılından önce de Çerkes göçünün yaşandığından bahsedilmektedir. Branisllav Nushiq'e göre, 1858-1862 yılları arasında Kosova’ya 6.000 Çerkes ailesi göç etmiştir ${ }^{69}$.

1864 yılında Karadeniz kıyısındaki limanlara çıkan Çerkeslerin Rumeli’ye dağıtılmalarına başlanmasıyla birlikte Çerkesler Kosova'ya da sevk edilmişlerdir. Kosova Ovası'nda iskân edilmek üzere 1.500 hâne Çerkes haziran ayında bölgeye gönderilmiştir ${ }^{70}$.

Kosova Ovası geniş ve iskâna uygun bir yerdi. Fakat çoğu yeri susuzdu ve böyle eski bir yerleşim yerinde zirâatin tekrar canlandırılması zahmetli olacaktı ${ }^{71}$. Kosova'daki yerel yönetim Çerkeslerin mağdur olmamaları ve iskânlarının sorunsuz bir şekilde gerçekleşmesi için çabalamışır ${ }^{72}$. Çerkeslerin Kosova'ya geleceklerinin belli olmasından sonra Prizren Sancağı Mutasarrıflığı, 10 Haziran'dan önce iskân hazırlıklarına girişmiştir. İskân için gerekli olan 1.500 evin inşasına, uygun görülen yerlerde yöre halkının yardımlarıyla başlanılmıştır. Ayrıca muhacirlerin kışlık buğday, fasulye ve darı gibi zahîreleri yetiştirmeleri için, Vulçıtrın ve Priştine kazaları

67 Malcolm, age., s. 239-240.

68 Machiel Kiel, "Prizren", Türkiye Diyanet Vakfi Íslam Ansiklopedisi, C 34, Türkiye Diyanet Vakfi İslam Araştırmaları Merkezi, İstanbul 2007, s. 350.

69 Osmani, age., s. 40.

70 BOA, A.\}MKT.MHM. 303-89-1 1281.M.17 (22.06.1864).

71 Cerîde-i Havâdis, 4 Temmuz 1864, No: 1200, s. 1.

72 BOA, A.\}MKT.MHM. 314-39 1281.Ca.08 (09.10.1864). 
halkı tarafından nadasa bırakılmış olan tarlaları kullanmalarına izin verilmiştir. Ziraat için gerekli olan öküz, araba ve çift aletleri satın alınmaya başlanmıştır. Diğer zaruri ihtiyaçlarının karşılanması için de bölgedeki devlet memurları ve ileri gelen kişilerden para toplanmasına karar verilmiştir.

Prizren Sancağı Mutasarrıflığının muhacirlerin ihtiyaçlarını karşılayabilmek için Kosovalılardan toplanacak yardımların dışında 12 yük kuruştan fazla akçeye ihtiyacı vardı. Bu dönemde Prizren sancağının gelirleri azalmıştı. Muhacirlerin masrafları sancağın bütçesini daha da bozmaktaydı. Mutasarrıflık, bu durum karşısında sorunun Sadârete bildirilmesine ve Priştine kazasında 1845 yılından beri tahsil edilemeyen alacakların tahsil edilerek muhacirlere zahire alınmasında kullanılmasına karar vermiştir ${ }^{73}$.

Kosova'ya yerleştirilecek olan Çerkesler muhacirlerin Rumeli'ye dağıtılmasında merkez olarak kullanılan yerlerden birisi olan Tuna Nehri kıyısındaki Lom şehri üzerinden bölgeye sevk edilmişlerdir. Lom'da toplanan Çerkeslerin 15.000 kadarı Niş ve Kosova taraflarında iskân edilmek üzere Büyük Balkan yoluyla Niş'e gönderilmiştir ${ }^{74}$. Avusturya'nın Belgrad Başkonsolosu, 15 Haziran 1864 tarihli raporunda Ürgüp, Kurşunlu ve Kosova'ya yerleştirilecek olan 2.000 muhacir ailesinin Niş’e ulaştı̆̆ını açıklamıştır ${ }^{75}$. Çerkesler kendilerini toparlamak için üç gün Niş'te kalmışlardır. Çok hasta olan 1.000 kadar muhacir ayrılarak uygun hânelere yollanmıştı ${ }^{76}$. Çerkeslerden 3.000'inin Niş, Şehirköy, Ürgüp ve İznepol taraflarında iskân edilmesine karar verilmiştir ${ }^{77}$. Kalan 11.000'den fazla Çerkes Kosova Ovası ile Vasovik taraflarına sevk edilmiştir. Bunların dışında 500 haneden fazla bir Çerkes topluluğunun da bölgeye gönderilmesi kararı alınmışır ${ }^{78}$.

Niş’ten Kosova'ya gönderilen Çerkesler Ürgüp ve Priştine'ye kadar Lom, Berkofça, Şehirköy, Ürgüp ve Leskofça kazalarından tedarik edilen arabalarla taşınmışlardır. Söz konusu kazaların halkı ve özellikle Şehirköy ve Niş Bulgarları, Çerkesleri sevk edilecekleri mahallere kendi arabalarıyla götürmüşler ve ihtiyaçlarını karşlamışlardır. Muhacirler için Niş, Şehirköy, Ürgüp, İznepol ile Priştine ve Vasovik taraflarında köyler ve mahalleler kurulmuştur.

Takvîm-i Vekâyi, 1 Ağustos 1864, No: 759, s. 1.

Osmani, age., s. 30.

Cerîde-i Havâdis, 4 Temmuz 1864, No: 1200, s. 1.

Takuîm-i Vekâyi, 1 Ağustos 1864, No: 759, s. 1.

Cerîde-i Havâdis, 4 Temmuz 1864, No: 1200, s. 1. 
Kosova ve Niş taraflarına temmuz ayında bir kez daha muhacir gönderilmiştir. Köstence üzerinden gelen 12.000 hâne Çerkes; Kosova, Vasovik ve İştib taraflarından başlayarak Niş, Sofya ve Berkofça sancaklarına sırasıyla iskân edilmiştir ${ }^{79}$.

Kosova'ya haziran ayında gönderilen 1.500 hâne Çerkes, Prizren Mutasarrıfi Nazif Paşa tarafindan eylül ayının ilk haftasına kadar olan dönemde ${ }^{80}$, kendileri için inşa edilen köylere ve evlere yerleştirilmiştir ${ }^{81}$. Rûznâme-i Cerîde-i Havâdis gazetesinin 15 Eylül 1864 tarihli sayısında çıkan bir haberde, son olarak Priştine kazasına 48 hâneden ve 480 kişiden oluşan bir Çerkes topluluğunun iskân edildiği belirtilmektedir ${ }^{82}$.

Kosova'ya gelen Çerkeslerin bir kısmı iskân edilmek üzere Yenipazar sancağına gönderilmiştir. Ancak burayı yurt edinemeyen 500 hâne Çerkes, tekrar Kosova'ya dönmüştür ${ }^{83}$.

1864 yılında Kosova'ya iskân edilen Çerkeslerin toplam sayısına ilişkin olarak kaynaklarda farklı bilgiler verilmektedir. Tercümân-ı Ahvâl gazetesinin 26 Şubat 1865 tarihli sayısında, 7.000-8.000 kadar Çerkes’in iskân edildiği yazmaktadır ${ }^{84}$. Noel Malcolm, Çerkes tarihinde, 2.000 ailenin Kosova'ya yerleştiğinin kabul edildiğini ve muhtemelen Kosova'ya göç eden Çerkes sayısının 12.000'i geçmediğini belirtmektedir ${ }^{85}$. Jusuf Osmani ise bugünkü Kosova topraklarına yaklaşık olarak 40.000 Çerkes’in iskân edildiğinin tahmin edildiği ve bazı kaynaklara göre 1.500 Çerkes ailesinin geldiği bilgisini vermektedir ${ }^{86}$.

Kaynakların önemli bir kısmında Kosova'ya ve çevresindeki bölgelere gönderilen Çerkeslerin sayısının birlikte verilmesi, bunların ne kadarının Kosova'da iskân edildiğinin tespit edilmesini zorlaştırmaktadır. Kosova'ya yerleştirilen Çerkeslerin sayısının gerçeğe en yakın bir şekilde belirlenmesinde muhacirler için inşa edilen evlerin sayısı önem taşımaktadır.

Takvîm-i Vekâyi, 1 Ağustos 1864, No: 759, s. 1.

Rûznâme-i Cerîde-i Havâdis, 7 Eylül 1864, No: 946, s. 1.

BOA, A. \}MKT.MHM. 318-28-1 1281.C.16 (16.11.1864).

Rûznâme-i Cerîde-i Havâdis, 15 Eylül 1864, No: 952, s. 1.

BOA, A.\}MKT.MHM. 318-28-1 1281.C.16 (16.11.1864). Günümüzde Yenipazar şehrinde halk arasında Çerkes Mahallesi olarak isimlendirilen bir mahalle bulunmaktadır.

Tercümân-ı Ahvâl, 26 Şubat 1865, No: 610, s. 2.

Malcolm, age., s. 270.

Jusuf Osmani ayrıca Balkanlar'da en fazla Çerkes'in Kosova'ya yerleştirildiğini belirtmekte ve bir gezginin 1860-1870 yılları arasında Kosova'ya 40.000 Çerkes'in iskân edildiğine dair tahminini aktarmaktadır. Osmani, age., s. 21, 26, 40. 
Cumhurbaşkanlığı Devlet Arşivleri Başkanlığı Osmanlı Arşivinde yer alan konuyla ilgili belgelerdeki bilgilere göre, 1864 yllında Kosova'ya en az 2.000 hâne Çerkes iskân edilmiştir ${ }^{87}$. Bu muhacirlerin sayısının 8.000-10.000 ${ }^{88}$ kişi civarında olduğu kabul edilebilir. Ancak muhacirlerin sayısı hânelerdeki nüfusun yoğunluğuna göre, verilen sayılardan biraz daha düşük ya da biraz daha yüksek olabilir.

Kosova'ya Çerkes göçü bazı kaynaklarda verilen bilgilerin aksine 1864 yllıyla s1nırlı kalmamış ve 1865 yllında da devam etmiştir. 1865 yllında en az 120 hâne Çerkes Priştine’ye yerleştirilmiştir. Tuna vilâyetinden gelen bu muhacirlerin dişında 90 hânelik bir başka Çerkes topluluğu da 1864 ya da 1865 yllında Priştine civarındaki bazı köylerde iskân edilmiştir.

1864 ve 1865 ylllarındaki göçler birlikte değerlendirildiğinde, bu yıllarda Kosova'ya en az 2.210 hane Çerkesin yerleştirildiği anlaşılmaktadır ${ }^{99}$. Bu hanelerin toplam nüfusunun 9.000-11.000 kişi civarında olduğu söylenebilir. Yenipazar sancağına bağlı olan Mitroviça kazası gibi, o dönemde Prizren sancağına bağlı olmayan Kosova bölgelerindeki Çerkes nüfusu bu hesaplamada yer almamıştır. Hesaplamanın dışında kalan muhacirler de dikkate alındığında, iskân edilen nüfusa ilişkin verilen sayılar daha da yükselecektir.

Kosova'ya iskân edilen Çerkeslerin bazıları bir süre sonra, yasak olmasına rağmen bölgeden ayrılmıştır. 1865 yllında, Priştine'ye daha önce yerleşmiş olan 40 Çerkes’in Edirne'deki akrabalarının yanına göç etmesine Meclis-i Vâlâ-yı Ahkâm-ı Adliyye tarafindan şartlı olarak izin verilmiştir ${ }^{90} .1866$ yılında da Priştine'de devletin kendilerine verdiği arazilerin mülkiyeti konusunda Arnavutlarla çatışma yaşayan ve kendilerini güvende hissetmeyen 39 Çerkes, Şumnu'daki akrabalarının yanına göç etmiştir ${ }^{91}$.

Çerkes göçü Kosova'daki Müslüman nüfusu daha da arttırmıştır. Alman seyyah ve bilim adamı Johann Georg von Hahn’ın Prizren'de uzun süre kalmış olan Avus-

87 BOA, A.\}MKT.MHM. 318-28-1 1281.C.16 (16.11.1864).

88 Nüfus hesaplamaları yapılırken, Osmanlı Devleti’nin nüfus yapısını ele alan çalışmalar incelenerek hâne başına ortalama nüfus 4-5 kişi kabul edilmiştir.

89 BOA, A.\}MKT.MHM. 318-28-1 1281.C.16 (16.11.1864); BOA, A.\}MKT.MHM. 352-38-1 1282.Ş.29 (16.01.1866).

90 BOA, Meclis-i Vâlâ Evrakı (MVL) 1019-14-1 1281.9.29 (11.12.1865); BOA, MVL 1019-14-2 1282.B.26 (15.12.1865); BOA, MVL 1019-14-3 1282.Ş.04 (23.12.1865).

91 BOA, MVL 1023-29-1 1283.B.02 (10.11.1866); BOA, MVL 1023-29-2 1283.C.11 (20.10.1866); BOA, MVL 1023-29-3, 4, 5, 6 1283.B.01 (09.11.1866). 
turya Konsolosluğu ajanı Dr. von Petelenz’in açıkladığı sayılara dayanarak 1865 yllında verdiği bilgilere göre, Prizren'de toplam nüfus 11.540 haneydi. Bu nüfusun 8.400 hânesi Müslüman, 3.000 hanesi Ortodoks ve 150 hânesi Katolik'ti. Toplam nüfus 46.000 kişi olup, bunun 36.000’i Müslüman'dı ${ }^{92}$.

Kosova'ya iskân edilen Çerkesler Abzeh, Şapsı̆ğ, Besleney ve Mahuş gibi Adıge kabilelerinden oluşmaktayd. Adıgelerle birlikte Abhazlar da bölgeye gelmiştir ${ }^{93}$. Balkan kültürüne yabancı olan Çerkesler tarihî süreçte Kosova'ya gelen toplulukların sonuncusuydu. Bununla birlikte XVI. yüzyılda Kosova'ya gelen Türklerin arasında bir tane Çerkes sipahinin olduğu bilinmektedir.

Çerkesler Kosova'ya geldikten sonra kendileri için köyler kurulmuştur. Çerkeslerin yerleştiği köylerin sayısı zamanla 50'yi geçmiştir. Bu köylerin birkaç tanesi 100 kadar evin bulunduğu büyük yerleşimlerdi. Çoğunluğu ise en fazla 40-50 hâneli küçük köylerdi ${ }^{94}$.

Çerkeslerin iskân edildiği köylerin bazılarının isimlendirilmesinde Çerkes kelimesi kullanılmıştır. Günümüzde Çerkes adının geçtiği tek yerleşim yeri olarak Çerkez Sadovina kalmıştır. Çerkes köylerinin bir kısmının adlandırılmasında da padişahların isimleri ve lakapları kullanılmıştır ${ }^{95}$. Bu çalışmada tespit edilen, Çerkeslerin yerleştirildiği köyler şunlardır: Şükriye, Fethiye ${ }^{96}$, Babamusa $^{97}$, Muradiye (Muratli-

92 Kiel, agm., s. 350.

93 Gazi Çemişo, Kosova'da Kumukların da bulunduğunu dile getirmektedir. Gazi Çemişo, Dönüşün Ilk Adımlan, çev. İbrahim Çetao, Kafkas Derneği Yayınları, Ankara 2000, s. 28. Niko Županić, Kosova Çerkeslerinin çoğunluğunu Abzehlerin oluşturduğunu ve Miloşevo'da az sayıda Şapsı̆̆’ın yaşadığını belirtmektedir. Niko Županić, "Etnološki značaj kosovskih Čerkeza.”, Etnolog (Ljubljana), 5/6 (1933), s. 225. Meşbaş'e Yishakh’ın Kosova Çerkeslerini konu ettiği "Xexesxer-Çerkes Trajedisinin Balkanlar Sayfası" adlı tarihî romanında Adıge, Abzeh (Abdzah), Mahuş (Mehueş), Bjeduğ, Besleney, Vubıh, Abhaz, Çeçen, Berekhet, Koblı, Bă̆, Nawurze, Dawur gibi topluluk ve aile isimleri geçmektedir. Meşbaş'e Yishakh, Xexesxer-Çerkes Trajedisinin Balkanlar Sayfası, çev. Fahri Huvaj, Birinci Basım, Adıge Yayınları, Ankara 2017, s. 129, 209, 214, 224. Priştine’ye iskân edilen Adıge kabilelerinden birisi de Şapsığlardır. BOA, MVL 537-6-1 1284.M.07 (11.05.1867). İzzet Aydemir'e göre, Osmanlı Devleti’ne göç eden muhacirler arasında sayıları Adıgelerden ve Abhazlardan az olan ve her biri farklı bir göç süreci yaşayan Osetlere, Çeçenlere, Dağıstanlılara ve Adıge boylarından Kabardeylere Balkanlar'da rastlanmamaktadır. Aydemir, age., s. 111.

94 Malcolm, age., s. 269-270.

95 Osmani, age., s. 46.

96 BOA, A.\}MKT.MHM. 352-38-1 1282.Ş.29 (16.01.1866). Şükriye ve Fethiye köylerinin isimleri incelenen çalışmalarda yer almamaktadır.

97 BOA, MVL 537-6-1 1284.M.07 (11.05.1867); BOA, MVL 537-6-2 1284.Ra.12 (14.07.1867). Bazı belgelerde adı Babinmusa, Babimusa gibi farklı şekillerde geçen ve Babamusa köyüyle aynı 
je-Muradije, Miradia e Epërme), Nazifiye (Sazlı), Hayriye (Sllatina e Madhe ${ }^{98}$, İhsaniye-i Bâlâ (Ishanije-i Bala, Stanovci i Poshtëm, Donje Stanovce), İhsaniye-i Zir (Ishanije-i Zir, Lummadhi, Velika Reka) ${ }^{99}$, Dobreve ${ }^{100}$, Magure ${ }^{101}$, Aziziye (Miloşevo ${ }^{102}$, Mramor ${ }^{103}$, Uglarit, Goleshit, Medhiye (Medhija), İbadiye (Prelezi i Muhaxhirëve), Imhiye (Dobraja e Vogël), Fatih (Ribari i Vogël), Hasköy (Bardhi i Madh, Veliki Belaçevac), Bereketliye (Babushi i Muhaxhirëve), Suvidol (Suhadoll Çerkez, Suhadolli i Muhaxhirëve), Obiliç (Obiliqi, Glloboderi), Katundi i Ri, Talinovci i Muhaxhirëve (Çerkezëve), Softaj, Shtimja ${ }^{104}$, Çerkesko Selo ${ }^{105}$, Pomozotin, Graçka, Pojatiste, Drobeş, Pozharan, Çerkez Sadovina, Doburçan, Dumoş, Kaçibeg, Dumnica, Çerkezköy ${ }^{106}$, Büyükdere, Mazgit, Ayvalı, Hamidiye (Bivoljak), Sipol,

bölgede bulunan, Çerkeslerin yaşadığı bir yerleşim yerinden bahsedilmektedir. BOA, İrâde Dahiliye (İ.DH..) 534-37022-1 1281.C.05 (05.11.1864); BOA, Dahiliye Nezâreti Mektûbî Kalemi (BOA, DH.MKT.) 181-36-1 1311.N.06 (13.03.1894); BOA, DH.MKT. 181-36-2 1311.B.23 (30.01.1894); BOA, DH.MKT. 181-36-3 1309.11.13 (25.01.1894); BOA, DH.MKT. 181-36-4 1311.C.03 (12.12.1893); BOA, A.\}MKT.MHM. 326-86 1281.L.15 (13.03.1865). Fethiye ve Şükriye köyleri gibi, Babamusa köyünün ismi de incelenen eserlerde geçmemektedir.

98 BOA, A.\}MKT.MHM. 352-38-1 1282.Ş.29 (16.01.1866); Osmani, age., s. 46-47. Çerkeslerin yerleştirildiği köyler arasında Sazlı köyünden bahsetmeyen Nihat Berzeg, Sadi köyünün adını vermektedir. Berzeg, age., s. 228.

99 BOA, Teftişât-1 Rumeli Evrakı (Rumeli Müfettişliği)-Kosova Evrakı (TFR.I..KV...) 48-4796-1 1321.L.25 (14.01.1904); Osmani, age., s. 47, 67-70. İhsaniye-i Zir'e Abhazlar yerleştirilmiştir. Osmani, age., s. 44.

100 BOA, TFR.I..KV ... 48-4796-1 1321.L.25 (14.01.1904).

101 BOA, Teftişât-ı Rumeli Evrakı (Rumeli Müfettişliği) Arzuhaller (TFR.I..ŞKT.) 134-13398-1 1322.03.02 (15.05.1906); BOA, TFR.I..SSKT. 134-13398-2 1325.Za.04 (09.12.1907).

102 Aziziye 1864 yllında Kosova'ya gelen Çerkes aileler tarafindan kurulmuştur. Jusuf Osmani, Kolonizimi serb i Kosovës, Botimi i dytë, Karmine-Stanboll, Prishtinë 2010, s. 110.

103 Osmani, age., s. 39.

104 Jusuf Osmani’ye göre, Medhiya ile Talinovci i Muhaxhirëve aynı yer olabilir. Osmani, Çerkezët, s. 21, 46, 47, 62, 90-91, 95, 97.

105 Mirčeta Vemić’in belirttiği Çerkesko Selo köyünün bulunduğu mevkide günümüzde Mala Dobranja ve Velika Dobranja adlı yerleşim yerleri bulunmaktadır. Mirčeta Vemić, "Serbs in Kosovo and Metohija in the Second Half of the $19^{\text {th }}$ Century According to an Ethnic Map of a Part of Old Serbia”, Forum geografic. Studii şi cercetări de geografie şi protecţia mediului, X/2 (2011), s. 262.

106 Sabit Uka, 1877-1878 Yillarnda Güney Sirbistan'dan Arnavutlarn Göçü ve Kosova Ovasina Yerleşmeleri, çev. Kamil Bitiş, Kosova Cumhuriyeti Diaspora Bakanlığı, 2014, s. 69. 
Çiçavica, Sibovc, Vrelo, Rujce, Slovinje, Vraçevo, Godance, Slavkovce, Donji Livoç $^{107}$, Zveçan ${ }^{108}$, ve Çerkesler (Çerkezi) ${ }^{109}$.

1860'ların sonlarında ve 1870'lerin başlarında Kosova’yı gezmiş olan Miloş S. Milojeviç’in gezi notlarına göre, bölgedeki Çerkes köylerinden Aziziye’nin nüfusu 100-500 hane kadardı. Çerkesko Selo, Nazifiye ve Ayvalı'nın (Avalipotok) nüfusu ise 50-100 hane civarındaydı. Bu dört köyde Çerkesler dışında başka bir etnik-dinî grup yaşamıyordu ${ }^{110}$.

Çerkesler, Kosova'da köylerin dışında, Priştine, Prizren, İpek, Gilan, Vulçıtrın, Mitroviça, Podujeva, Lipjan, Vitina ${ }^{111}$, Firzovik (Ferizovik) $)^{112}$, Yakova (Gjakova) $)^{113}$ ve Graçaniça gibi şehir ve kasabalara da yerleşmişlerdir ${ }^{114}$.

\section{d. Kosova Çerkeslerine Yapılan Yardımlar}

Osmanlı Devleti Rumeli’ye iskân edilen diğer muhacirlere tanıdı̆̆ı gibi, Kosova Çerkeslerine de vergi muafiyeti tanımıştır ${ }^{115}$. Onlara öküz, tohum ve çeşitli tarımsal malzeme temin edebilmek için 1864 yılının Ekim ayına kadar olan dönemde 12 yük 90.000 kuruş masraf yapılmıştır ${ }^{116}$. İhtiyaçları giderilerek ve kendilerine verilen tarlaların sürdürülmesine başlanarak geçim sıkıntısı yaşamamalarının sağlanmasına çalışılmıştır. Ziraat yapmaları için gerekli olan arazinin memurlar vasıtasıyla taksim edilmesine ekim ayının başlarında devam edilmiştir. Satın alınan

107 Nihat Berzeg, Çerkeslerin Trepça'da da 2 köye yerleştiklerini belirtmektedir. Berzeg, age., s. 227229 .

108 Çemişo, age., s. 25.

109 Mitroviça yakınlarındaki Çerkesler köyü 1913 yılına kadar varlığını korumuştur. Redzep Škrijelj, "Eski Yugoslavya'da Boşnak ve Çerkes Muhacir Mahalleleri”, Geçmişten Günümüze Göç III, ed. Osman Köse, Canik Belediyesi Kültür Yayınları, Samsun 2017, s. 2157. Meşbaş'e Yishakh, tarihî romanında Kosova'da Çerkeslerin yaşadığı Bjeduğ ve Besleney köylerinden, Çeçenay adlı Bjeduğ köyünden, Labe köyünden, Abhaz ve Türk köylerinin de bulunduğu Priştine Dağları arasındaki vadide kurulmuş olan Abzeh ve Mahuş köylerinden, Dawurhable adlı Çerkes yerleşiminden ve bir Çeçen köyünden bahsetmektedir. Meşbaş’e, age., s. 129, 130, 132, 177, 178, 209, 214, 224, 336.

110 Vemić, agm., s. 255, 262.

111 Berzeg, age., s. 227-229.

112 BOA, Şûrâ-yı Devlet (ŞD.) 2458-10-5 1299.B.27 (14.06.1882).

113 Osmani, Çerkezët, s. 99.

114 Marieta Kumpilova, "Circassian Exodus from the North Caucasus and their Resettlement in Kosovo”, 1864 Kafkas Tehciri Kafkasya'da Rus Kolonizasyonu, Savaş ve Sürgün, ed. Mehmet Hacısalihoğlu, BALKAR \& IRCICA, İstanbul 2014, s. 439.

115 Malcolm, age., s. 270.

116 BOA, A.\}MKT.MHM. 314-39 1281.Ca.08 (09.10.1864). 
arabalar ve 100 çift öküzün dağıtımı yapılmıştır. Çerkesler yerli halkla birlikte ot ve ekin biçmeye başlamışlardır ${ }^{117}$.

Kosova'ya iskân edilen Çerkeslere bölgede görevli olan memurlar ve Kosovalılar da çeşitli yardımlarda bulunmuşlardır. Prizren Mutasarrıfı Nazif Paşa ile Prizren ve Priştine kazalarındaki halkın ve memurların bir kısmı, önemli miktarda akçe ve elbise bağışlamıştır. Bu durumun Takvîm-i Vekâyi'de duyurulmasına karar verilmiştir $^{118}$.

Prizren sancağında 1864 yılı ile 1865 yılının ilk aylarını içine alan dönemde Çerkesler için 1241 adet ev yapılmıştır ${ }^{119}$. Evlerin inşa edildiği yerler arasında Priştine kazası da yer almıştır. Burada 1864 yılında ilk gelen muhacirler için inşa edilen 620 evin üzerlerinin örtülmesi için 18.600 kuruş masraf yapılmıştır. Ayrıca muhacirlerin daha elverişli bir yere taşınan 90 hânesinin 6.300 kuruş tutan inşa ve kereste masrafları Sirinik (Sirinic) köyü halkı tarafından üstlenilmiştir. Bu 90 hanenin 37'si Dobreve Ovası'ndan Muradiye köyüne nakledilmiş ve 2.220 kuruş harcanmıştır. 16 hanesi Kubatın Ovası'ndan yine Muradiye köyüne taşınmış ve 1.120 kuruş masraf yapılmıştır. Kalan 37 hânesi de Şirokopole Ovası'ndan Fethiye köyüne gönderilmiştir. Bu 37 hânenin taşınması da 2.960 kuruşa mâl olmuştur.

Osmanlı Devleti Priştine'de Çerkeslere arazi de vermiştir. Priştine’ye 1864 yılında ilk gelen muhacirlerin arazilerinin sürdürülme masrafi kaza halkı tarafindan karşılanmıştır. Priştineliler arazilerin sürdürülmesi için 2.150 adet pulluğa 53.750 kuruş ödemişlerdir ${ }^{120}$.

Priştine kazasında Çerkeslerin ihtiyaç duyduğu ibadet yerlerinin yapılması da ihmâl edilmemiştir. 200 haneden fazla Çerkes'in iskân edildiği Babimusa adlı yerde cami bulunmadığı için mahalli yönetim, 1864 yılının sonlarında mescit inşa edilmesi için çalışmalara başlamıştır. Mescidin yapımında bölgede daha önce ordu için inşa edilmiş olan 4 adet terk edilmiş firının enkazından alınacak malzemenin kullanılmasına karar verilmiştir ${ }^{121}$.

117 Takvîm-i Vekâyi, 10 Ekim 1864, No: 769, s. 1.

118 BOA, A.\}MKT.MHM. 314-100 1281.Ca.15 (16.10.1864). Bu konuda ayrıca bk. Yücel Yiğit, "Kosova Çerkezleri”, Geçmişten Günümüze Göç III, ed. Osman Köse, Canik Belediyesi Kültür Yayınları, Samsun 2017, s. 2177.

119 Rûznâme-i Cerîde-i Havâdis, 19 Haziran 1865, No: 181, s. 4; Takvîm-i Vekâyi, 29 Haziran 1865, No: 806, s. 4.

120 BOA, А. MKT.MHM. 352-38-1 1282.Ş.29 (16.01.1866).

121 BOA, İ..DH.. 534-37022-1 1281.G.05 (05.11.1864); BOA, İ..DH.. 534-37022-2 1281.Ş.16 
Priştine’ye Çerkes göçü 1865 yılında da devam etmiştir. Kazada Tuna vilâyetinden yeni gelen muhacirler için 120 ev daha inşa edilmiş ve 26.400 kuruş masraf yapılmıştır. Bu masrafin 11.739 kuruşu hazineden karşılanmıştır.

Priştine'ye göç eden Çerkesler için yerleştikleri köylerde kuyular da açtırılmıştır. 4'ü 1864 yılında gelenler için ve 4'ü de 1865 yılında gelenler için olmak üzere 8 adet kuyu kazılmıştır. Bu kuyuların 2 tanesi Hayriye köyünde, 2 tanesi Şükriye köyünde, 2 tanesi Nazifiye köyünde ve 2 tanesi de Fethiye köyünde açtırılmıştır. Kuyuların inşası için 4.624 kuruş harcanmış ve bu tutarın 2.170 kuruşunu hazine karşılamıştır ${ }^{122}$.

Priştine kazasına 1864-1865 yıllarında gelen Çerkeslerin yukarıda bahsettiğimiz arazilerinin sürdürülmesi, köylerinde kuyular açtırılması, evlerinin inşa edilmesi ve üzerlerinin örtülmesi gibi işleri için toplam olarak 109.674 kuruş harcanmıştır. Bu masrafin 16.609 kuruşunu Priştine Mal Sandığı, 93.065 kuruşunu kaza halkı karşılamıştır ${ }^{123}$. Priştinelilerin yaptıkları bu yardımlardan gazetelerde onurlu bir davranış ve sadâkat olarak bahsedilmiştir ${ }^{124}$.

Kosova'da Çerkesler için evler inşa edilen yerlerden birisi de Yenipazar sancağına bağlı Mitroviça kazasıydı. Burada da Çerkeslere tarımsal destek olarak öküzler ve çeşitli zirâî malzemeler verilmiştir. Kazada muhacirler için 1865 yılının Mart ayına kadar olan dönemde 81.583 kuruş masraf yapılmıştır. Bu tutarın 40.050 kuruşunu yöre halkı karşılamıştır ${ }^{125}$. 1866 yılında da muhacirlerin tohumluk almalarına katkı sağlamak için kaza halkının ve memurlarının bir kısmı nakdî yardımda bulunmuştur ${ }^{126}$.

(14.01.1865); BOA, İ..DH.. 534-37022-3 1281.Ş.29 (28.01.1865); BOA, İ..DH.. 534-37022-4 1281.N.22 (18.02.1865); BOA, İ..DH.. 534-37022-5 1281.L.07 (05.03.1865); BOA, A.\}MKT. MHM. 326-86 1281.L.15 (13.03.1865). Babimusa adı bir belgede Babinmusa olarak geçmektedir. BOA, İ..DH.. 534-37022-1 1281.G.05 (05.11.1864).

122 BOA, A.\}MKT.MHM. 352-38-1 1282.Ş.29 (16.01.1866).

123 BOA, А.\}MKT.MHM. 352-38-1 1282.Ş.29 (16.01.1866); BOA, А.\}MKT.MHM. 352-38-2 1282.Za.04 (21.03.1866). Tasvir-i Efkâr gazetesinin 2 Nisan 1866 tarihli sayısında yer alan bir haberde de Priştine kazasına yerleştirilen muhacirler için inşa edilen evlerin 93.065 kuruş tutarındaki masrafinın kaza halkı tarafından karşılandığı belirtilmektedir. Necdet Hayta, Tarih Araştırmalarna Kaynak Olarak Tasvir-i Efkâr Gazetesi (1278/1862-1286/1869), T.C. Kültür Bakanlığı Yayınları, Ankara 2002, s. 189. Aynı haber Takuîm-i Vekâyi gazetesinin 3 Nisan 1866 tarihli sayısında da yer almaktadır. Takvîm-i Vekâyi, 3 Nisan 1866, No: 839, s. 2.

124 BOA, A.\}MKT.MHM. 352-38-3 1282.Za.12 (29.03.1866).

125 Takuîm-i Vekâyi, 13 Mart 1865, No: 790, s. 3.

126 Takuîm-i Vekâyi, 27 Kasım 1866, No: 867, s. 1. 
Osmanlı yönetimi, 1866 yılında Gilan, Priştine ve Vulçıtrın kazalarındaki Çerkeslerden kuraklık sebebiyle mahsul alamayanlara ve fakir olanlara bir sonraki senenin hasat zamanına kadar yarım gündelik verilmesine ve hastalık sebebiyle hayvanları ölenlere bedeli taksitlerle ödenmek şartıyla öküz temin edilmesine karar vermiştir ${ }^{127}$.

\section{e. Çerkeslerin Kosova'ya Uyum Süreci ve Yaşadıkları Sorunlar}

Çerkesler metal işçiliği ve at yetiştiriciliğinde uzmanlaşmışlardı. Gümüş işçiliği ve özellikle tabanca kabzası ve kamçı sapı süslemesinde uygulanan Rus tula üslubunda ustaydılar ${ }^{128}$. Kosova'ya iskân edildikten sonra devlet tarafindan zirâat yapmaya teşvik edilen Çerkeslerin bir kısmı, daha önce icrâ ettikleri zanaatı burada da yapmaya devam etmiştir ${ }^{129}$. Çerkesler yeni memleketlerinde zamanla değirmencilikle de uğraşmaya başlamışlardır ${ }^{130}$.

Kosova Çerkesleri arasında devlet hizmetine girenler de olmuştur. Kosova'daki yerel yönetimlerde görev alanlar içinde lakabı Çerkes olan kişilere rastlanmaktadır. 1873 yılında Prizren vilayetinin Gilan kazasında Meclis-i Deâvî azâsı olarak görev yapan Çerkes Yakub Efendi bu kişilerden birisidir ${ }^{131}$.

Kosova'ya yerleşen Çerkesler Osmanlı ordusuna da hizmet etmişlerdir ${ }^{132}$. Kosova vilâyetinin Vulçıtrın kazasına bağlı İhsaniye-i Bâlâ köyünde yaşayan Asâkir-i Muâvene-i Çerâkise yüzbaşılarından Devlet Mirza'ya, Kosova vilayetindeki durum hakkında bilgi vermesi ve Çerkes muhacirler ile yerli halk arasında yaşanan anlaşmazlıkların sona erdirilmesi gibi hükûmetten verilen bütün görevleri iyi bir şekilde yerine getirmesi sebebiyle 1881 yılında bir adet beşinci rütbeden mecîdî nişânı verilmesi kararlaştırılmıştır ${ }^{133}$.

Çerkesler, Kosova'ya geldikten sonra eğitim hizmetlerinden de faydalanmaya başlamışlardır. Bazı Çerkes öğrenciler Prizren Medresesine devam etmiştir ${ }^{134}$.

127 BOA, MVL 1023-10-1, 2 1283.Ş.12 (20.12.1866).

128 Malcolm, age., s. 270-271.

129 Takvîm-i Vekâyi, 10 Ekim 1864, No: 769, s. 1.

130 Çemişo, age., s. 61.

131 Salnâme-i Devlet-i Aliyye-i Osmaniyye, 1290, Defa 28, s. 58.

132 BOA, Bâb-ı Âli Evrak Odası (BEO) 517-38726-1 1312.Ca.19 (18.11.1894).

133 BOA, İ..DH.. 828-66700-1 1298.Ca.24 (24.04.1881); BOA, İ..DH.. 828-66700-2 1298.C.23 (22.05.1881).

134 Osmani, Çerkezët, s. 100. 
Kosova Çerkesleri devletin sağladığı desteğe ve bölge halkının yardımlarına rağmen yeni vatanlarında geçim sıkıntısı yaşamışlardır ${ }^{135}$. Bir kısmı asayiş sorunlarına yol açmış ve yaklaşık 40 defa yerleri değiştirilmiştir ${ }^{136}$. Bazıları da isyan çıkartma teşebbüsünde bulunmuştur. 1867 yılı Mayıs ayında Prizren'de ve Priştine'de isyan çıkmıştır. Bunun üzerine bölgeye askerî birlik sevk edilmiştir ${ }^{137}$.

Çerkesler, Kosova'ya yerleştikten sonra diğer Müslümanlardan ayrı bir hayat sürdürmeye başlamışlardır. Bu durum Türkler ve Arnavutlar tarafından hoş karşılanmamıştır ${ }^{138}$. Heterojen bir nüfus yapısına sahip olan bölgede dillerini uzun süre muhafaza etmişlerdir. Ancak karmaşık bir yapıda olan dillerine diğer kültürlerden bazı sözcüklerin geçmesine engel olamamışlardır ${ }^{139}$.

Çerkesler İslamiyet'in etkisiyle benimsedikleri Arapça isimleri Kosova'da da kullanmaya devam etmişlerdir. Bununla birlikte Çerkes isimlerini de terk etmemişler$\operatorname{dir}^{140}$. Birçok köydeki mezar taşlarında Adıgece soyadları bulunmaktadır ${ }^{141}$.

Kosova Çerkesleri dilleri gibi, geleneklerini ve toplumsal yapılarını da uzun süre korumuşlardır. Zengin olan Çerkesler beraberlerinde kölelerini ve onların ailelerini de Kosova'ya getirmişlerdi. Kosova'da da pazarlarda köle çocuklarını satma adetlerini sürdürmüşlerdir ${ }^{142}$.

\section{4. Çerkeslerin Kosova'dan Ayrılmaları}

Kosova'ya iskân edilen Çerkeslerin büyük bir kısmı burada kalıcı olmamıştır. Kosova'ya gelişlerinden 13 yıl sonra, yaşadıkları sıkıntıların azalmaya başladığı ve yeni hayat şartlarına alıştıkları bir dönemde bölgeyi terk etmek zorunda kalmış$\operatorname{lardır}^{143}$. Balkan Krizi’nin (1875-1878) yarattığı siyasî atmosfer, Çerkeslerin ikinci defa zorunlu göçe maruz kalmalarına yol açacak gelişmelere zemin hazırlamıştır. 1876'da çıkan Bulgar İsyanı'na Kosova Çerkesleri de müdahale etmiştir ${ }^{144}$. Bulgar

135 Malcolm, age., s. 270.

136 Grassi, age., s. 118.

137 Pinson, agm., s. 64.

138 Osmani, Çerkezët, s. 45.

139 Malcolm, age., s. 270.

140 Osmani, Çerkezët, s. 147.

141 Çemişo, age., s. 25.

142 Malcolm, age., s. 270-271.

143 Kumpilova, agm., s. 440.

144 Malcolm, age., s. 271. 
İsyanı'nın bastırılmasında Çerkeslerin önemli bir rol oynamasından rahatsız olan Avrupa devletleri, 23 Aralık 1876'da toplanan İstanbul Konferansı'nda Çerkeslerin Rumeli'den gönderilmelerini ve bölgeye tekrar iskân edilmemelerini istemişlerdir ${ }^{145}$.

Kosova Çerkesleri 1877-1878 Osmanlı-Rus Savaşı'nda da Osmanlı ordusunun yanında takviye kuvvet olarak yer almışlardır ${ }^{146}$. Bu savaş da Çerkeslerin tarihindeki kırılma noktalarından birisi olmuştur. Savaşın başlamasıyla birlikte Çerkesler Rumeli'yi terk etmeye başlamışlardır ${ }^{147}$.

Balkanlar'ın birçok yerindeki Çerkesler gibi, Kosova'daki Çerkesler de 1877 yılında iç bölgelere göç etmişlerdir ${ }^{148}$. Bu göç 1878 yllında devam etmiştir ${ }^{149}$. Bununla birlikte savaş sırasında Sırp ordusundan kaçan Niş, Leskofça, İvranye (Vranje), Şehirköy (Pirot) ve Toplica gibi yerlerdeki Çerkesler, Müslüman Arnavutlarla beraber Kosova'ya gelmişlerdir ${ }^{150}$.

Çerkeslerin tekrar Balkanlar’a dönmelerine izin verilmemesi konusunda Avrupa devletlerinin baskılarına maruz kalan Osmanlı Devleti, 8 Mart 1879'da Çerkeslerin Rumeli’ye dönmesini yasaklamışıı ${ }^{151}$. Çerkeslerin bölgede kalan emlâk ve arazilerinin Rumeli muhacirlerine verilmesine ve Çerkeslere Anadolu'da yer gösterilmesine karar verilmiştir ${ }^{152}$. Çerkeslerin Kosova'da terk ettiği köylere ve mahallere Surbistan'ın güneyinden gelen Arnavutlar yerleştirilmiştir ${ }^{153}$.

1878 yllında Kosova'dan ve Selânik'ten Anadolu'ya ve Arabistan'a göç eden Çerkesler, Osmanlı Devleti tarafindan tekrar Balkanlar’a yerleşmeleri yasaklanmış

145 İsmail Hakkı Uzunçarşılı, "Tersane Konferansının Mukarreratı Hakkında Şûra Mazbatası", Istanbul Üniversitesi Edebiyat Fakültesi Tarih Dergisi, VI/9 (1954), s. 125., Dipnot: 2.

146 Malcolm, age., s. 271.

147 BOA, İ..DH.. 764-62280-4 1295.S.27 (02.03.1878).

148 BOA, DH.MKT. 2724-25 1327.M.08 (31.01.1909).

149 BOA, А.\}MKT.MHM. 484-25-1 1295.02.10 (22.04.1879); BOA, А.\}MKT.MHM. 484-25-2 1295.02.14 (26.04.1879).

150 Aleksandre Popovic, Balkanlarda İslâm, çev. Komisyon, İnsan Yayınları, İstanbul 1995, s. 220.

151 Özbek, age., s. 162.

152 BOA, ŞD. 2427-28-2 1296.Z.19 (03.12.1879).

153 BOA, ȘD. 277-48-1 1296.B.23 (12.07.1879); BOA, ȘD. 277-48-2 1296.B.19 (08.07.1879); BOA, ŞD. 277-48-3 1296.B.16 (05.07.1879); BOA, ŞD. 2458-10-1 1299.L.29 (12.09.1882); BOA, ŞD. 2458-10-2 1299.L.10 (24.08.1882); BOA, ŞD. 2458-10-3 1299.N.09 (24.07.1882); BOA, ŞD. 2458-10-4 1299.Ş. 17 (04.07.1882); BOA, ŞD. 2458-10-5 1299.B.27 (14.06.1882); BOA, DH.MKT. 1340-46-4 1299.Za.29 (11.10.1882); BOA, DH.MKT. 2724-25 1327.M.08 (31.1.1909). 
olmasına rağmen 1879 yilında geri dönmeye başlamışlardır ${ }^{154}$. Bunun üzerine Osmanlı Devleti, Çerkeslerin vapurlara binmelerini önlemek için kumpanya vapurlarının acentelerini hiçbir Çerkes yolcu almamaları konusunda uyarmışıır ${ }^{155}$. Kosova'ya ulaşmayı başaran Çerkesler, evlerine Arnavutların yerleştirilmesi sebebiyle evsiz kalmışlardır ${ }^{156}$.

1877-1878 Osmanlı-Rus Savaşı'nın çıkmasından sonra başlayan göçler sonucunda Kosova'daki Çerkes nüfusu azalmıştır. Bölgedeki Çerkeslerin sayısı 1890'lı yılların sonlarında yaklaşık olarak 6.400 kişiye kadar düşmüştür ${ }^{157} 1909$ yılına gelindiğinde, Kosova vilayetinin Vulçıtrın, Priştine, Gilan ve Kumanova kazalarında yaklaşık olarak 350 hâne Çerkes kalmıştır ${ }^{158}$.

Karadağ'ın 8 Ekim 1912'de Osmanlı Devleti'ne savaş ilan etmesiyle başlayan Balkan Savaşları, Kosova Çerkesleri için yeni bir göç sürecini başlatmıştır. Savaşın çıkmasından kısa bir süre sonra Sırp ordusu tarafından işgal edilen Kosova'daki Çerkeslerin büyük çoğunluğu, bölgedeki diğer Müslümanlarla birlikte Osmanlı Devleti’nin daha güvenli topraklarına göç etmiştir. Kosova, I. Balkan Savaşı sonunda imzalanan 30 Mayıs 1913 tarihli Londra Antlaşması'yla Sırbistan Krallığı'na bırakılmıştır. Böylece Kosova'da kalan Çerkesler için yeni bir dönem başlamiştir.

Çerkesler Sırbistan Krallığı döneminde de Kosova'dan ayrılmaya devam etmişlerdir. 1918 yılından sonra büyük bir göç yaşanmıştır. Ancak Kosova'daki Çerkes varlığı tamamen sona ermemiştir. Nitekim Avusturyalı bir antropolog, Yugoslavya Krallığı zamanında, 1931 yılında Priştine ile Vulçıtrın arasındaki Donje Stanovce köyünde mavi gözlü, Kafkasya kökenli 50 ailenin yaşadığını belirlemiştir ${ }^{159}$.

II. Dünya Savaşı'ndan sonra Kosova'da yaklaşık olarak 100 Çerkes evi kalmıştır. Birçoğu Yugoslavya Federal Halk Cumhuriyeti döneminde, 1956 yılında Türki-

154 BOA, A.\}MKT.MHM. 484-25-1 1295.02.10 (22.04.1879); BOA, А.\}MKT.MHM. 484-25-2 1295.02.14 (26.04.1879); BOA, A.\}MKT.MHM. 484-25-3 1295.02.18 (30.04.1879).

155 BOA, A.\}MKT.MHM. 484-25-4 1296.Ca.09 (01.05.1879); BOA, A.\}MKT.MHM. 484-25-5 1296.Ca.21 (13.05.1879).

156 BOA, ŞD. 2458-10-4 1299.Ş.17 (04.07.1882); BOA, ŞD. 2458-10-5 1299.B.27 (14.06.1882); BOA, Yıldız Perakende Evrakı Askerî Maruzat (Y..PRK.ASK.) 50-21 1306.M.03 (10.09.1888).

157 Malcolm, age., s. 271.

158 BOA, DH.MKT. 2729-24-1 1324.11.11 (24.01.1909); BOA, DH.MKT. 2729-24-2 1327.M.12 (04.02.1909).

159 Malcolm, age., s. 271. 
ye'ye göç etmek için mülklerini satmıştır ${ }^{160}$. 1956-1958 ylllarında Donje Stanovce köyünden 60 aile Türkiye'ye göç etmiş ve yerlerine Arnavutlar yerleşmiştir ${ }^{161}$.

1980'li yılların başlarında Donje Stanovce köyündeki ve yakınındaki Miloşevo köyündeki Çerkes ailelerinin sayısını 50 civarında olduğu tespit edilmiştir. Bu ailelerin toplam nüfusunun 600-700 kişi arasında olduğu tahmin ediliyordu ${ }^{162}$. 1990'lı ylların ortalarına gelindiğinde ise Priştine'de 2, Donje Stanovce'de 25 ve Miloşevo'da 12 Çerkes ailesi yaşıyordu ${ }^{163}$.

Kosova Çerkesleri anavatana dönme arzularını nesiller boyu korumuşlardır. Kafkasya'ya göç etmeyi, Yugoslavya'da etnik çatışmaların yaşanmaya başlamasından sonra 1990'lı yılların başlarında daha ciddi bir şekilde düşünmeye başlamışlardır. Bu dönemde Adıgey Cumhuriyeti'nin başında Aslan Carım'ın bulunması, Kosova Çerkesleri için önemli bir şans olmuştur. Cumhurbaşkanı Aslan Carım, Kosova'da yaşayan Çerkeslerin ülkesine gelmesini istiyordu. Bu isteğin gerçekleşmesi için çalışmalar 1990 yılında başlamışııı ${ }^{164}$. Adıgey Cumhuriyeti'ne göç etmek isteyen Çerkesler, 1996 yllında vatandaşlık için Rusya Federasyonu'na mürâcaat etmişlerdir ${ }^{165}$.

Kosova'da 1998 yllında çıkan savaş, Çerkeslerin de güvenliğini tehdit etmeye başlamış ve Adıgey Cumhuriyeti'ne göç sürecini hızlandırmışıı' ${ }^{166}$. Kosova Çerkeslerinin durumunun görüşülmesi için Yugoslav ve Rus temsilciler arasında 24 Temmuz 1998'de Belgrad'ta bir toplantı yapılmıştır. Toplantıda Çerkes ailelerden Adıgey Cumhuriyeti'ne yerleşmek isteyenlere izin verilmesi konusunda anlaşma sağlanmıştr. 134 yıl sonra, 1 Ağustos 1998'de 21 aileden 86 kişi Kosova'dan ayrılarak Adıgey Cumhuriyeti’ne göç etmiştir. Adıgey Cumhuriyeti’nde 1 Ağustos tarihi, "Vatanına Dönenlerin Günü" ilan edilmiştir. Kosova Çerkeslerinin Adıgey Cumhuriyeti'ne göçleri 1999 yılında da devam etmiştir. 1998-1999 yıllarında toplam olarak 38 aileden 165 kişi Adıgey Cumhuriyeti’ne göç etmiştir ${ }^{167}$.

\footnotetext{
160 Osmani, Çerkezët, s. 100-101.

161 Çemişo, age., s. 32.

162 Malcolm, age., s. 271.

163 Çemişo, age., s. 39.

164 Çemişo, age., s. 143-144.

165 Çemişo, age., s. 61.

166 Çemişo, age., s. 81-93.

167 Çemişo, age., s. 145-163.
}

Belleten, Aralık 2021, Cilt: 85/Say1: 304; 991-1024 
Kosova'da son göçten sonra Donje Stanovce ve Miloşevo köylerinde az sayıda Çerkes kalmıştır. Donje Stanovce'de kalan Çerkesler Tsey, Haçe, Jevu ve Gute ailelerine mensuptu. ${ }^{168}$ Kosova'dan ayrilmayan Çerkeslerin çoğunluğu Arnavutlarla ve Sırplarla evlilik yapanlar ve yaşlılard ${ }^{169}$. Bunlar arasında Çerkes dili bilenlerin sayısı çok azd1 $1^{170}$.

Kosova Çerkeslerinin bir kısmı da zamanla Arnavutlaşmıştır. Çerkesler, Kosova'daki nüfus sayımlarında kendilerini Arnavut veya Türk olarak kaydettirmekte ya da az sayıdaki azınlıkların yazıldığı diğerleri kısmında göstermektedirler. Bu sebeple günümüzde Kosova'da ne kadar Çerkes'in yaşadığını sağlıklı bir şekilde tespit etmek güçtür.

\section{Sonuç}

Rusya'nın Kafkasya'da kurmak istediği hâkimiyetin önünde engel gördüğü Çerkesleri Kırım Savaşı'ndan sonra Osmanlı Devleti topraklarına ve Kuban bölgesine göçe zorlamasıyla birlikte Çerkes göçleri başlamıştır. Osmanlı Devleti’nin bu dönemde tek başına, Rusya'nın Kafkasya'yı işgal etmesini ve Çerkesleri yurtlarından sürmesini engelleyebilecek gücü yoktu. Müslüman nüfusunu arttırmaya ihtiyaç duyan ve Çerkeslerden iktisadi ve askerî alanda faydalanmak isteyen Osmanlı yönetimi, muhacirleri kabul etmiştir.

Çerkes göçleri Rus ordusunun 1864 yılı Mayıs ayında Çerkesleri mağlup etmesinden sonra yoğunlaşmıştır. Osmanlı Devleti muhacirleri Anadolu'ya, Ortadoğu'ya ve sık sık isyanların yaşandığı Balkanlar'a iskân etmeyi planlamıştır. Çerkeslerin Balkanlar'daki iskân yerlerinin belirlenmesinde en başta güvenlik politikası etkili olmuştur. Bölgedeki askerî gücün Ruslara ve Sırplara karşı arttırılması için Sırbistan sınırına ve Tuna Nehri boylarına 150.000 ile 250.000 arasında Çerkes yerleştirilmiştir.

Çerkeslerin Rumeli'de iskân edildiği yerlerden birisi de Sırbistan ile sınırı olan Kosova bölgesi olmuştur. 1864 yllında bölgeye en az 2.000 hane Çerkes iskân edilmiştir. Göç 1865 yllında da devam etmiştir. 1865 yllında Tuna vilayetinden gelen 120 hâne Çerkes Priştine'ye yerleştirilmiştir. Söz konusu muhacirler Tuna vilayetinden geldiği için bunların göçü, bir iç göç olarak da değerlendirilebilir.

168 Çemişo, age., s. 27-28.

169 Çemişo, age., s. 176.

170 Osmani, Çerkezët, s. 145. 
1864 ve 1865 ylllarındaki göçler birlikte incelendiğinde, bu yıllarda Kosova’ya en az 2.210 hâne Çerkes’in iskân edildiği görülmektedir. Bu muhacirlerin toplam nüfusunun 9.000-11.000 kişi civarında olduğu kabul edilebilir. Bu nüfus miktarının, aynı yıllarda Rumeli'ye yerleştirilen Çerkeslerin yaklaşık olarak \% 4-6'sını oluşturduğu söylenebilir. Söz konusu yıllarda Prizren sancağının dışındaki Kosova bölgelerine iskân edilen Çerkes nüfus da hesaplamaya dahil edilirse bu sayılar daha da yükselecektir.

Kosova'ya Adıgelerle birlikte Abhazlar da göç etmiştir. Bölgeye bütün Adıge kabileleri gelmemiştir. Muhacirlerin çoğunluğu kırsal bölgelere yerleştirilmiştir. En az 66 yerleşim yerine iskân edilmişlerdir. Daha ziyade Kosova'nın orta kesiminde bulunan bu yerleşim yerlerinin 54'ü köy, 12'si şehir ve kasabadır. Söz konusu köylerden 19 tanesinin adı Türkçedir. Diğer köyler içinde adı başlangıçta Türkçe olup, sonradan Arnavutça ya da Sırpça isim alanlar olmuş olabilir. Bazı köylerin isimlerinde Çerkes kelimesi kullanılarak muhacirlerin kimliği ön plana çıkarılmıştır. Ayrıca Osmanlı Devleti'nin diğer bölgelerinde olduğu gibi, Kosova'da da Çerkes köylerinin bir kısmına isim olarak padişahların adları ve lakapları verilmiştir.

Çerkeslerin Kosova'ya iskân edilme süreci iyi idare edilmiş̧ir. Bunda Prizren Mutasarrıfı Nazif Paşa önemli bir rol oynamıştır. Kosova halkı da Çerkeslere çok yardım etmiştir. Çerkeslerin mağduriyet yaşamaması için yerel yönetim ve halk işbirliği yapmıştır. Muhacirlerin iskân masraflarının karşılanmasında Prizren sancağının bütçesi yeterli olmamıştır. Sorun Kosova halkının yardımlarıyla aşılabilmiştir. Bazı yerlerde masrafların yarısına yakınını Kosovalılar karşılamıştır. Bazı yerlerde de halk, devletin yaptı̆̆ı harcamanın 5-6 kat fazlasını yapmışıır.

Çerkesler, Kosova'ya iskân edildikten sonra doğal olarak uyum sorunu ve geçim sıkıntısı yaşamışlardır. Yerli halkla da aralarında bazı sorunlar çıkmışıı. Bu sorunlara daha çok, arazi mülkiyeti gibi konularda yaşanan anlaşmazlıklar sebep olmuştur. Çerkesler kültürlerini Kosova'da da büyük ölçüde korumuşlardır.

Çerkeslerin Kafkasya'daki makûs talihleri Rumeli'de de değişmemiş̧ir. Balkan Krizi'nin (1875-1878) çıkmasından sonra Çerkeslerin bir defa daha zorunlu göçe maruz kalmalarına yol açacak gelişmeler yaşanmıştır. Balkanlar'daki Müslüman nüfusun artmasından ve bölgede çlkan isyanların bastırılmasında Çerkeslerin kullanılmasından rahatsız olan Avrupa devletleri, 23 Aralık 1876'da toplanan İstanbul Konferansı'nda Çerkeslerin Rumeli'den çıkarılmasını istemişlerdir.

1877-1878 Osmanlı-Rus Savaşı, Avrupa devletlerinin Çerkeslerle ilgili isteklerinin büyük ölçüde gerçekleşmesini sağlamıştır. Savaşın başlamasından sonra Çerkesler 
Balkanlar'dan ayrılmaya başlamışlardır. Kosova Çerkeslerinin önemli bir kısmı da iskânlarının üzerinden 13 yıl geçtikten sonra yurtlarını terk etmek zorunda kalmıştır. 93 Harbi, Kosova'daki Çerkeslerin ilk defa kitlesel bir şekilde bölgeden ayrılmalarına ve nüfuslarının erimeye başlamasına sebep olan bir savaş olarak tarihe geçmiştir.

1877-1878 Osmanlı-Rus Savaşı gibi, Balkan Savaşları da Kosova Çerkeslerinin tarihindeki dönüm noktalarından birisi olmuştur. Kosova'daki Çerkes nüfusu I. Balkan Savaşı'nda Sırp ordusunun Kosova'yı işgal etmesinden sonra daha da azalmıştır. Kosova'nın savaş sonunda imzalanan 30 Mayıs 1913 tarihli Londra Antlaşması'yla Sırbistan Krallı̆̆ı'nın hâkimiyetine girmesinden sonra Kosova Çerkeslerini yeni sıkıntıların beklediği bir dönem başlamıştır.

Kosova Çerkeslerinin yaşadıkları mağduriyetler Sırbistan Krallığı ve Yugoslavya dönemlerinde de devam etmiştir. Bu durum, Kosova'dan yeni göçlerin yaşanmasına ve bölgedeki Çerkes nüfusunun erime sürecinin devam etmesine yol açmıştır.

Çerkeslerin Kosova'dan son büyük göçleri, birçoğunun bir gün dönmeyi umut ettikleri anavatanlarına olmuştur. 1998 yılında Sırp-Arnavut çatışmalarının yoğunlaşmasıla birlikte 1998-1999 yıllarında 150'den fazla Çerkes, Adıgey Cumhuriyeti’ne göç etmiştir. Bu göç, Kosova'daki Çerkes varlığını bitme noktasına getirmiştir.

Sonuç olarak, 1864-1865 yıllarında Kafkasya'dan Anadolu’ya ve Ortadoğu'ya göç eden Çerkeslerin önemli bir kısmı, bu bölgelere kalıcı bir şekilde yerleşmiştir. Ancak Balkanlar'da yaşanan tarihsel süreç, Kosova'yı ve Rumeli’yi Çerkesler için geçici bir yerleşim yeri haline getirmiştir. Osmanlı Devleti'nin Çerkes nüfusun Rumeli’ye iskân edilmesiyle elde etmeyi umduğu kazanımlar büyük ölçüde gerçekleşmemiştir. Kosova'da Çerkeslerin iskânından sonra Müslüman nüfus ve üretime katılan insan sayısı artmıştır. Ancak Çerkeslerin Kosova'daki varlığı ve Osmanlı ordusuna verdikleri destek, bölgedeki Osmanlı hâkimiyetinin korunması için yeterli olmamıştır. Kosova'daki Çerkesler 1877-1999 yılları arasında Avrupa'nın diğer bölgelerine, Anadolu'ya, Ortadoğu'ya ve Kafkasya'ya göç etmişlerdir. Kosova’ya yapılan Çerkes göçünün geride kalan tek hatırası, Çerkeslerin Kosova tarihinde bıraktıkları iz ve Kosova kültürüne kazandırdıkları zenginlik olmuştur. 


\section{KAYNAKLAR}

\section{Arşiv Belgeleri}

Cumhurbaşkanlığı Devlet Arşivleri Başkanlığı Osmanlı Arşivi (BOA)

\section{A. Bâb-1 Âli Belgeleri}

1. Bâb-1 Âli Evrak Odası (BEO)

517-38726-1.

\section{Bâb-1 Âli Sadâret Dairesi Kalemleri}

\section{a. Hazine-i Evrak Müdürlüğü-İrâdeler}

İâde Dahiliye (İ..DH..), 534-37022-1, 2, 3, 4, 5; 764-62280-4; 828-66700-1, 2.

\section{b. Sadâret Mektûbî Kalemi Belgeleri}

Sadâret Mektûbî Mühimme Kalemi (A. \}MKT.MHM.), 303-89-1, 2, 3; 305-94-1; 314-39; 314-100; 318-28-1; 326-86; 352-38-1, 2, 3; 484-25-1, 2, 3, 4, 5.

\section{Meclis-i Vâlâ (MVL)}

537-6-1, 2; 1019-14-1, 2, 3; 1023-10-1, 2; 1023-29-1, 2, 3, 4, 5, 6.

4. Şûrâ-yı Devlet (ŞD.)

277-48-1, 2, 3; 2427-28-2; 2458-10-1, 2, 3, 4, 5.

B. Nezâretlere, Taşra Arşivlerine ve Müfettişliklere Ait Belgeler

1. Dahiliye Nezâreti

Dahiliye Nezâreti Mektûbî Kalemi (DH.MKT.), 181-36-1, 2, 3, 4; 1340-46-4; 2724-25; 2729-24-1, 2.

\section{Taşra Evrakı-Bosna Müfettişliği Evrakı (TŞRBNM.)} 19-13-1, 2.

\section{Teftişât-1 Rumeli Evrakı (Rumeli Müfettişliği)}

Arzuhaller (TFR.I..ŞKT.), 134-13398-1, 2.

Kosova Evrakı (TFR.I..KV...), 48-4796-1. 


\section{G. Yıldız Sarayı Arşivi Belgeleri}

\section{Yildız Perakende Evrakı}

Yıldız Perakende Evrakı Askerî Maruzat (Y..PRK.ASK.), 50-21.

Yıldız Perakende Evrakı Komisyonlar Maruzatı (Y..PRK.KOM.), 3-22-1; 3-24-3, 4 .

\section{Salnâmeler}

Salnâme-i Devlet-i Aliyye-i Osmaniyye, 1280, Defa 18.

Salnâme-i Devlet-i Aliyye-i Osmaniyye, 1281, Defa 19.

Salnâme-i Devlet-i Aliyye-i Osmaniyye, 1282, Defa 20.

Salnâme-i Devlet-i Aliyye-i Osmaniyye, 1285, Defa 23.

Salnâme-i Devlet-i Aliyye-i Osmaniyye, 1286, Defa 24.

Salnâme-i Devlet-i Aliyye-i Osmaniyye, 1287, Defa 25.

Salnâme-i Devlet-i Aliyye-i Osmaniyye, 1288, Defa 26.

Salnâme-i Devlet-i Aliyye-i Osmaniyye, 1289, Defa 27.

Salnâme-i Devlet-i Aliyye-i Osmaniyye, 1290, Defa 28.

Salnâme-i Devlet-i Aliyye-i Osmaniyye, 1292, Defa 30.

Salnâme-i Devlet-i Aliyye-i Osmaniyye, 1293, Defa 31.

Salnâme-i Devlet-i Aliyye-i Osmaniyye, 1294, Defa 32.

Salnâme-i Devlet-i Aliyye-i Osmaniyye, 1295, Defa 33.

Salnâme-i Vilâyet-i Kosova, 1296, Defa 1, Priştine 1296.

\section{Gazeteler}

Cerîde-i Havâdis, 1200 numaralı sayı.

Rûznâme-i Cerîde-i Havâdis, 181, 884, 928, 946, 952 numaralı sayılar.

Takuîm-i Vekâyi, 757, 759, 769, 790, 804, 806, 839, 867 numaralı sayllar.

Tercümân-ı Ahvâl, 610 numaralı sayı. 


\section{Kaynak ve Telif Eserler}

Ahbab, Yakup, “Tanzimat Dönemi İdari Düzenlemelerinin Üsküp Eyaleti’nde Tatbiki”, Türkiyat Mecmuasi, 25/2 (2015), s. 1-30.

Aktepe, Münir, "Kosova", Türkiye Diyanet Vakfi İslam Ansiklopedisi, G 26, Türkiye Diyanet Vakfı İslam Araştırmaları Merkezi, Ankara 2002, s. 216-219.

Aydemir, İzzet, Göç: Kuzey Kafkasya’llarn Göç Tarihi, Gelişim Matbaası, Ankara 1988.

Berzeg, Nihat, Çerkesler Kafkas Sürgünü: Vatansız Brrakılan Bir Halk, Birinci Basım, Chiviyazıları Yayınevi, İstanbul 2006.

Çemişo, Gazi, Dönüşün İlk Adımları, çev. İbrahim Çetao, Kafkas Derneği Yayınları, Ankara 2000.

Erdem, Ufuk, Osmanl'dan Cumhuriyet'e Muhacir Komisyonlan ve Faaliyetleri (18601923), TTK Yayınları, Ankara 2018.

Grassi, Fabio L., Yeni Bir Vatan. Çerkeslerin Osmanl Imparatorluğu’na Zorunlu Gö̧̧ü (1864), çev. Birgül Göker Perdisa, 2. baskı, Tarihçi Kitabevi, İstanbul 2017.

Hayta, Necdet, Tarih Araştırmalarna Kaynak Olarak Tasviri-i Efkâr Gazetesi (1278/18621286/1869), T.C. Kültür Bakanlığı Yayınları, Ankara 2002.

Hayta, Necdet-Ünal, Uğur, Osmanl Askerî Gazetesi Cerîde-i Askeriyye 1-30, Berikan Yayınevi, Ankara 2010.

Kandur, Muhittin, Bir Balkan Öykïsü, çev. Özge Öztürk, Apra Yayıncılık, İstanbul 2017.

Karpat, Kemal H., "Avrupalı Egemenliğinde Müslümanların Konumu Çerkeslerin Sürgünü ve Suriye'deki İskanı”, Çerkeslerin Sürgünü 21 Manıs 1864 (Tebliğler, Belgeler, Makaleler), 1. baskı, Kafkas Derneği Yayınları, Ankara 2001, s. 78-111.

Karpat, Kemal H., Osmanlidan Günümüze Etnik Yapılanma ve Göçler, Timaş Yayınları, İstanbul 2010.

Kasumov, Aliy-Kasumov, Hasan, Çerkes Soykrmm: Çerkeslerin XIX. Yüzynl Kurtulus Savaşı Tarihi, çev. Orhan Uravelli, Kafkas Derneği, Ankara 1995.

Kaya, Yalçın, Çerkesler-I- Tarih-Mitoloji-Gelenek, Dahi Yayıncılık, İstanbul 2015. 
Kaya, Yalçın, Çerkesler -III- Sürgün ve Soykırm, Dahi Yayıncllk, İstanbul 2015.

Kiel, Machiel, "Prizren", Türkiye Diyanet Vakfi İslam Ansiklopedisi, C 34, Türkiye Diyanet Vakfi İslam Araştırmaları Merkezi, İstanbul 2007, s. 349-351.

Koyuncu, Aşkın, "Tuna Vilâyeti'nde Nüfus ve Demografi (1864-1877)", Turkish Studies, 9/4 (2014), s. 675-737.

Kumpilova, Marieta, "Circassian Exodus from the North Caucasus and their Resettlement in Kosovo", 1864 Kafkas Tehciri Kafkasya'da Rus Kolonizasyonu, Savaş ve Sürguin, ed. Mehmet Hacısalihoğlu, BALKAR \& IRCICA, İstanbul 2014, s. 421-446.

Malcolm, Noel, Kosova: Balkanlan Anlamak İ̧̧in, çev. Özden Arıkan, 1. baskı, Sabah Kitapları, İstanbul 1999.

Meşbaş'e, Yishakh, Xexesxer-Çerkes Trajedisinin Balkanlar Sayfası, çev. Fahri Huvaj, Birinci Basım, Adıge Yayınları, Ankara 2017.

Natho, Kadir, Kafkasya'da ve Kafkasya Dışındaki Çerkesler, çev. Ömer Aytek Kurmel, Birinci Basım, Kaf-Dav Yayınları, Ankara 2009.

Osmani, Jusuf, Çerkezët në Kosovë, Olymp, Prishtinë 2014.

Osmani, Jusuf, Kolonizimi serb i Kosovës, Botimi i dytë, Karmine-Stanboll, Prishtinë 2010 .

Özbek, Yediç Baturay, Çerkes Tarihi Kronolojisi, Ankara 1991.

Pinson, Marc, "Kırım Savaşı’ndan Sonra Osmanlılar Tarafından Çerkeslerin Rumeli’ne İskanı”, Çerkeslerin Sürgünü 21 Mayns 1864 (Tebliğler, Belgeler, Makaleler), Kafkas Derneği Yayınları, Ankara 2001, s. 52-77.

Popovic, Aleksandre, Balkanlarda İslâm, çev. Komisyon, İnsan Yayınları, İstanbul 1995.

Richmond, Walter, Çerkes Soykrrmm, çev. Erdoğan Boz, Koyusiyah Yayıncllı, Ankara 2018.

Şemseddin Sâmi, Kâmûsül'-a lâm, G V, Mihran Matbaası, İstanbul 1314.

Škrijelj, Redzep, "Eski Yugoslavya'da Boşnak ve Çerkes Muhacir Mahalleleri", Geçmişten Günümüze Gö̧̋ III, ed. Osman Köse, Canik Belediyesi Kültür Yayınları, Samsun 2017, s. 2153-2161. 
Uka, Sabit, 1877-1878 Yillarnda Güney Sirbistan'dan Arnavutlarn Göçü ve Kosova Ovası'na Yerleşmeleri, çev. Kamil Bitiş, Kosova Cumhuriyeti Diaspora Bakanlığı, 2014.

Uzunçarşılı, İsmail Hakkı, "Tersane Konferansının Mukarreratı Hakkında Şûra Mazbatası", İstanbul Üniversitesi Edebiyat Fakültesi Tarih Dergisi, VI/9 (1954), s. 123140 .

Ünlü, Mucize, Kosova Vilayeti, Gece Kitaplığı, Ankara 2014.

Vemić, Mirčeta, "Serbs in Kosovo and Metohija in the Second Half of the $19^{\text {th }}$ Century According to an Ethnic Map of a Part of Old Serbia", Forum geografic. Studï şi cercetări de geografie şi protecţia mediului, X/2 (2011), s. 255-263.

Yiğit, Yücel, "Kosova Çerkezleri”, Geçişten Günümüze Göç III, ed. Osman Köse, Canik Belediyesi Kültür Yayınları, Samsun 2017, s. 2171-2178.

Županić, Niko, "Etnološki značaj kosovskih Čerkeza.", Etnolog (Ljubljana), 5/6 (1933), s. 218-253. 